\title{
Another Perspective of The Effects of Migration as A Determinant of Foreign Direct Investment: Evidence-Based on Panel Gravity Model from Turkey and OECD Countries
}

Hande AKSÖZ-YILMAZ (https://orcid.org/0000-0002-1115-7535), Kirşehir Ahi Evran University, Turkey; hande.yilmaz@ahievran.edu.tr

\section{Doğrudan Yabancı Yatırımın Belirleyicisi Olarak Göçün Etkilerine Farklı Bir Bakış: Türkiye ve OECD Ülkeleri Üzerine Panel Çekim Modelinden Bulgular}

\begin{abstract}
This paper aims to investigate the impact of immigration on FDI between Turkey and OECD countries. The paper uses data spanning the period 2003-2019. There is employed PPML estimation method which presented efficient output in the presence of heteroskedasticity and non-large zero values of inward FDI in Panel Gravity Model. However, outward FDI is estimated using the ZINB model for outward FDI data has overdispersion and excess zero flows. The results show that immigrant flows to OECD from Turkey on the FDI flows are relatively more effective than the immigrant flows to Turkey from OECD.

Keywords $\quad$ : Migration, Foreign Direct Investment, PPML Estimation Method.

JEL Classification Codes: $\quad$ C23, F22, F23.

Öz

Bu çalışma, Türkiye ve OECD ülkeleri arasındaki Doğrudan Yabancı Yatırım akışları üzerinde göçün etkisini incelemeyi amaçlamaktadır. Bu amaçla, çalışma 2003-2019 dönemini kapsayan verileri kullanmaktadır. Panel Çekim Modelinde değişen varyansın ve içe dönük DYY'lerde büyük sayıda olmayan sıfır gözlem değerlerinin varlığında etkin sonuçlar sunan PPML tahmin yöntemi uygulamaktadır. Bununla birlikte, dışa doğru DYY'ler, aşırı dağılıma ve aşırı sıfır değerine sahip olan dışa doğru DYY verileri nedeniyle ZINB modeli kullanılarak tahmin edilmektedir. Sonuçlar, Türkiye'den OECD'ye giden göçmenlerin DYY'ler üzerindeki etkisinin, OECD'den Türkiye'ye gelen göçmenlere göre daha etkili olduğunu göstermektedir.
\end{abstract}

Anahtar Sözcükler $\quad$ : Göç, Doğrudan Yabancı Yatırım, PPML Tahmin Yöntemi. 
Aksöz-Y1lmaz, H. (2021), “Another Perspective of The Effects of Migration as A Determinant of Foreign Direct Investment: Evidence-Based on Panel Gravity Model from Turkey and OECD Countries”, Sosyoekonomi, 29(50), 169-196.

\section{Introduction}

Immigrant groups living outside their source countries create various formal and informal cooperation channels. These cooperation's have customarily been based on relationship, language, and country of origin characteristics. They were set up relatively to ensure support for those in need, particularly new immigrants. As an ethnic immigrant community increases its population, these institutions begin to serve as information exchange centres between the supply and demand of investments, both regionally and internationally.

The fundamental ground of the literature is that international trade and investment transactions are struggling with unofficial trade barriers, in addition to official trade barriers such as transportation costs and tariffs (Javorcik et al., 2011: 232). Access to information on many topics, including potential market opportunities and difficulties in executing contracts across national borders, are among these barriers. The language skills of immigrants and compatibility with a foreign country can significantly reduce communication costs. In both economies, knowledge of market structure, consumer preferences, work ethic, and trade structures are important in establishing new business contacts. Similarly, information sharing and enforcement of contracts across national boundaries are also very important in investment decisions. FDI activities face more significant information asymmetry than international trade transactions. Labour, raw material cost, distributors, and sectoral characteristics are meaningful in evaluating the profitability of an investment-related project. FDI requires long-term business interaction and detailed knowledge. If foreign investors know little about the country they will invest in, they will encounter many difficulties. Any foreign investor should be sure of the reliability of the legal system of the country of investment for the reliability of their agreements with their stakeholders. Therefore, investment barriers can be high in countries where institutional effectiveness is limited, and the legal environment does not provide sufficient security (Gao, 2003: 612; Ligthart \& Singer, 2009: 3; Javorcik et al., 2011: 231-2). Immigrants contribute to overcoming barriers in investment issues and reducing investment costs, increasing the investment volume between the homeland, and receiving countries.

As in all developing countries, Turkey needs direct foreign investments in its economic development, growth, and current account balance. Turkey's domestic savings and resources are insufficient for realizing the necessary investments in the development of Turkey. This situation reveals the mandatory need of Turkey for foreign direct investments. The importance of foreign direct investments for Turkey can also be seen in the development plans prepared in 5-year periods. Encouraging foreign direct investments has been one of the policies emphasized in the eighth, ninth, and tenth development plans. The Tenth Development Plan has adopted the principle of ensuring the improvement of the investment environment by implementing incentives and supporting FDI policies and making progress in bureaucratic and legal processes. By focusing on the priority problems of the business and investment environment, it aims to eliminate the uncertainties faced by the investors and solve the problems rapidly, increasing investments by improving the existing mechanisms 
(Republic of Turkey Ministry of Development, 2014). This paper mainly aims to understand to what extent the immigrant flows between Turkey-OECD countries have fostered FDI flows between Turkey-OECD countries over the period 2003-2019. To achieve this goal, we use data based on migration, FDI, demographic-economic property, and the geographical distance of 20 OECD countries. This study seeks to answer the question "What is the impact of the immigrant flows between Turkey and OECD countries on the FDI between OECD countries and Turkey?"

The hypotheses of the paper are constituted as follows:

Hypothesis-1: The immigrant flows between 20 OECD countries and Turkey positively affect the inward FDI to Turkey from 20 OECD countries over the period 2003-2019.

Hypothesis-2: The immigrant flows between Turkey and 20 OECD countries positively affect the outward FDI from Turkey to 20 OECD countries over the period 2003-2019.

This paper analyses impact of the immigrant flows between OECD and Turkey on FDI flows between Turkey and OECD countries. There are important reasons for using FDI and migration data of Turkey and OECD countries to analyse the link between FDI and migration flows. Primarily, OECD countries host more than half of the total Turkish immigrant stock globally, and OECD countries make a significant majority of total inward FDI to Turkey. Also, the considerable literature in the past has engaged in substantial discussion on selecting the appropriate model and the estimation technique in the analysis of this relationship. Zero FDI flows are an important problem in the analysis of FDI flows. Indeed, Helpman et al. (2008: 443) also report that 50\% of the 158 countries in its sample have zero trade flows. Bergeijk and Brakman (2010) emphasize that if the gravity equation is applied to FDI flows, this number will exceed $80 \%$. The standard procedure for solving zero FDI flows is to drop the zero flows from the sample or add a small constant to all FDI flows to estimate a log-linear equation. Silva \& Tenreyro (2006) suggest the PPML estimation method, which provides efficient, consistent estimators by keeping the zero values of the dependent variable in the model. The PPML method suffers from underpredicting the number of zero observations. When faced with a sample containing many zeros, the two-stage estimation method (Bosker \& Garretsen, 2010). However, although two-stage estimation provides an avenue of using information from zero trade observation and has a theoretically sound method, it is difficult to satisfy the exclusion restriction because the instrumental variable is often challenging to find (Burger et al., 2009; Brakman et al., 2010). To deal with zero FDI flows, Brakman et al. (2010) proposed a zeroinflated approach- The Zero-Inflated Negative Binomial (ZINB) model- as used by Lambert (1992). ZINB method is the generalized form of the Poisson model and has few restrictions as it does not assume normality as in the two-stage estimation. Zero Inflated Models have good performance as they correct for excessive zeros and excessive distribution in the dependent variables. 
Aksöz-Y1lmaz, H. (2021), "Another Perspective of The Effects of Migration as A Determinant of Foreign Direct Investment: Evidence-Based on Panel Gravity Model from Turkey and OECD Countries”, Sosyoekonomi, 29(50), 169-196.

This paper focuses on the FDI and immigrant flows between Turkey and OECD countries based on the explanations above. The contributions of the paper to the international economics literature are threefold. First, this study reveals the relationship between the two main production factors, human and capital mobility, for Turkey and OECD countries, indicating a significant relationship between them ${ }^{1}$. Second, zero FDI flows are an important problem in the analysis of FDI flows. To solve zero outward FDI flows, we consider the ZINB model suggested by Brakman et al. (2010) as an alternative to the two-stage estimation in the analysis of FDI flows. Our third contribution is based on these explanations. While the inward FDI model is estimated using the PPML estimator, in the outward FDI model, the ZINB estimator is preferred instead of the PPML estimator because the PPML method suffers from underpredicting the number of zero observations. Therefore, a key strength of our paper is that it is the first empirical paper that tests with the PPML method to the nonlinear model link between immigration and inward FDI flows and which tests with the ZINB method to the link between immigration and outward FDI flows under the case of OECD countries and Turkey in the extant international economics literature.

The rest of the paper is organized as follows: section 2 presents literature investigating the links between migration and FDI flows worldwide. Section 3 introduces the methodology. Variables, definitions, and data sources are given in Section 4. Model and Result the findings are introduced in Section 5. Section 6 concludes with findings and some policy recommendation.

\section{Literature Review}

Most of the studies on FDI reveal the relationships between the determinants of FDI and economic growth. FDI is under the influence of factors such as large regional market, good infrastructure, commercial openness, human capital intensity, wage level, and political stability (Cheng \& Kwan, 2000: 380; Asiedu, 2002: 115; Ali \& Guo, 2005: 26; Wahid et al., 2009: 8; Alfaro \& Chen, 2010: 22; Bal \& Akça, 2016: 109). On the other hand, foreign investors may face more difficulties if they are unfamiliar with the host country's legal regulations, language, and business relations. Immigrants facilitate their investments in the countries of their origin through the network channel. With the contribution of globalization, the speedy growth of the foreign population and investment in many countries in recent years has urged a lot of analysis on the determinants of migration and FDI flows. The earliest studies investigated the relationship between immigrant networks and bilateral foreign trade (Gould, 1994: 314; Head \& Ries, 1998: 60-1; Dunlevy \& Hutchinson, 1999/2001: 1058/21; Girma \& Yu, 2002:128-9; Rauch \& Trindade, 2002: 129; Combes et al., 2002: 23; Bellino \& Giuseppe, 2016: 25). Immigrants also bring their individual and corporate information based on their country of origin to destination countries. These social networks can reduce potential difficulties and barriers to international investment, as immigrants have vital

1 Several empirical studies have been devoted to human mobility rather than taking account capital mobility (Gould, 1994: 314; Head \& Ries, 1998: 60-1; Dunlevy \& Hutchinson, 1999/2001: 1058/21; Girma \& Yu, 2002: 128-9; Rauch \& Trindade, 2002: 129; Combes et al., 2002: 23; Bellino \& Giuseppe, 2016: 25). 
knowledge of market characteristics, preferences, business ethics, and business rules. This leads to the promotion of investment activities between countries (Garas et al., 2016: 3). Emerging international economics literature suggests that immigrant networks can help overcome information barriers to international capital flows and may increase inward FDI to their country of origin. The relationship between FDI and migration has been considered from two divergent manners in the international economics literature. The first one is the studies that take advantage of the theoretical research. These studies prioritized theoretical foundations. The theoretical foundations of FDI are underlined by Helpman (1984) and Markusen (1995) based on investment location by emphasizing the role of multinational corporations (MNCs). Barry (2002) made the first systematic study to theoretically address the relationship between FDI, infrastructure, labour migration, and domestic welfare. The second is the studies discussing the FDI flows within the social structure in the context of the immigrant network. These studies mainly focused on empirical analysis by taking advantage of the gravity model (Gao, 2003: 617; Tong, 2005: 564; Ligthart \& Singer, 2009: 5; Garas et al., 2016:15).

Ethnic and social networks take on a critical mission in promoting countries' FDIs. Rauch and Trindade (2002) are pioneering studies examining the economic effects of immigrants' ethnic and social networks. Rauch and Trindade (2002) emphasize primarily that ethnic Chinese networks increase bilateral trade through formal and informal intercourse. Gao (2003) and Tong (2005) empirically investigate the role of ethnic Chinese networks in promoting FDI. Gao (2003) finds a significant positive effect in inward FDI of ethnic Chinese networks in the investing country. Tong (2005) found that ethnic Chinese networks are significant in catalysing cross-border investment between countries. Also, he suggests that ethnic Chinese networks are more effective in promoting FDIs to countries with higher bureaucratic quality. Ligthart and Singer (2009) emphasize that migrant networks encourage FDI in countries with relatively weak institutions. When the institutional quality is relatively poor, the incentive power of migrant networks increases FDI significantly.

Ethnic networks serve as a consequential channel of information about business conditions and advantages abroad (Javorcik et al., 2011: 231-2). The size of the foreign origin group living in any country positively affects the FDI flows from that group's country of origin. On the one hand, Buch et al. (2006) find that German states with a sizeable foreign population from the same country of origin have more stocks of FDI. On the other hand, Bhattacharya and Groznik (2008) express those U.S. investments in a foreign country are positively affected by the size of the foreign-origin group from that country living in the U.S. Likewise, Javorcik et al. (2011) suggest that the outward FDI flows from the US. are correlated with migrants from the host country. Ligthart and Singer (2009) empirically research the role of immigrants in Dutch outward FDI. They find that immigrant flows are significant in facilitating outward FDI to their countries of origin. Murat et al. (2008) analysed the link between migrant networks and Italian FDI using the model (OLS-IV) based on the stocks of Italian emigrants abroad and immigrants in Italy. They thus evaluate how institutional and economic development of source and destination countries affect network 
connections by drawing attention to informal barriers that can create informal barriers to socio-cultural and institutional differences between countries and encourage international investment decisions. Studies based on national-level data face some identification problems. Investment and migration drain to prosperous countries, bordering countries, steady political orders, and a common language. These similarities lead to an identity problem. Foad (2012) examined the regional distribution of FDI and immigration in the U.S., taking into account identification problems and reveals how immigrants in the U.S. states attract FDI from their source countries to the U.S. He seeks the answer to the question of whether immigration actually causes FDI or is mainly affected by the same unobserved variable.

FDI decisions are made depending on many economic factors. Clemens and Williamson (2000) examine which countries and motives the British capital go as FDI. They conclude that the British capital goes abroad to natural resources, educated populations, immigrants, and young populations. Clemens and Williamson's (2000)'s paper suggests that immigrant flows have a vital role in the FDI. Factors such as institutional quality, deepened financial system, and the importance of law have vital effects on international capital flows. Similarly, Tong (2005) evaluates that the destination country's economic growth and institutional development and its source country do not affect the immigrant network. Malan (2015) stated that both east-west migrations positively impact FDI flows, and west-east FDI flows have positively influenced the east-west migration since the 1990s, considering the existence of an endogenous relationship between FDI and migration. However, empirical studies have shown that FDI and migrant flows are much more than complementary (Gao, 2003: 623-4; Tong, 2005: 576-7; Buch et al., 2006: 2032; Murat et al., 2008: 11-2; Bhattacharya \& Groznik, 2008: 243; Ligthart \& Singer, 2009: 18-9; Javorcik, 2011: 232; Foad, 2012: 257-8; Malan, 2015: 205; Garas et al., 2016: 23).

There are a limited number of studies at the point of investigating the connection between migration and FDI using Turkey's migration and FDI data. One of these limited studies is the Akkoyunlu (2010) which investigated the effect of FDIs on migration. Akkoyunlu (2010) explores the impact of FDIs on Turkish immigrants to Germany, while our study investigates the impact of migration on FDIs using data on migration and FDI between OECD and Turkey. Akkoyunlu (2010) stated that the increase in foreign direct investments positively impacts migration in the short run but negatively affects only in the long run. Özaydın and Ilgazi (2019) analysed the effects of investments made by businessmen of Syrian origin on the Turkish economy. They argued that investments of Syrian origin contributed positively to Turkey's economic growth. The contribution of our study is to analyse the migration-FDI link between Turkey and OECD countries. 
Aksöz-Y1lmaz, H. (2021), "Another Perspective of The Effects of Migration as A Determinant of Foreign Direct Investment: Evidence-Based on Panel Gravity Model from Turkey and OECD Countries”, Sosyoekonomi, 29(50), 169-196.

To put forward the linkage between immigrant and FDI flows, the overall approach uses the gravity model$^{2}$. (Gao, 2003: 617; Tong, 2005: 564; Ligthart \& Singer, 2009: 14; Malan, 2015; Garas et al, 2016: 23-4). Gao (2003) used the OLS estimation method because it did not encounter zero FDI problems in the gravity model, whose dependent variable is the log of cumulative FDI in China. Tong (2005) applied OLS and Tobit methods to estimate the gravity model, with OLS being the base model, considering the potential endogeneity of migration in FDI models significantly the estimation results ${ }^{3}$. To estimate the gravity model, Ligthart and Singer (2009) and Murat et al. (2008) explicitly controlled for the potential endogeneity of the immigrant and independent variables by using instrumental variables (IV) Tobit analysis. However, Malan et al. (2015) employed the Pseudo Poisson Maximum Vraissemblance (PPMV) method proposed by Silva and Tenreyro (2006) for the same endogeneity problem. Although Garas et al. (2016) used PPML as the baseline model in estimating the gravity model, they also employed a negative binomial regression model as an additional estimation technique to address the possibility that the dependent variable is over dispersed is not sufficiently described by a Poisson distribution.

\section{Methodology}

The gravity model originated from the fundamental gravitational equation in Newtonian physics and explained FDI flows between two countries by the size and distance between the two countries. The gravity model generally states the relationship between, on the one hand, flows between different locations and, on the other hand, the "weight" of these locations and the inverse of the distance (Bergeijk \& Brakman, 2010). Ravenstein (1885) stands out as a pioneering work using gravity models in social sciences, revealing that migration flows are oriented according to the absorption capacity of trade and industrial centres. He states that most immigrants go to neighbouring and close countries where they have job opportunities. Bertoli and Moraga (2017) expose, as with trade, that bilateral migration costs are an increasing function of physical distance. However, Tinbergen (1962) made the first mathematical formulation and empirical application of the gravity model and took its place in the international trade literature in explaining the trade potential between the two countries. Anderson and Van Wincoop (2003) developed some assumptions on the

2 To investigate the link between FDI and immigrant flows, Buch et al. (2006) used to agglomeration method, Bhattacharya \& Groznik (2008) found through their cross-section and panel data analyses, that a positive relationship exists between the variables.

3 Javorcik et al. (2011) stated that the problem of endogeneity arises because migration and FDI flows have impacts on each other. First, FDI inflows to a country mean the arrival of capital, new technology and knowledge. In this way, FDI fosters economic growth in host countries. The entry of multinational firms can increase employment and wages. Therefore, FDI entries can reduce people's desire to migrate. Later, local employees can be dispatched to organizations of the multinational company in other countries and FDI flows begin to have a positive impact on migration. 
Aksöz-Y1lmaz, H. (2021), "Another Perspective of The Effects of Migration as A Determinant of Foreign Direct Investment: Evidence-Based on Panel Gravity Model from Turkey and OECD Countries”, Sosyoekonomi, 29(50), 169-196.

microeconomic basis of traditional gravity equations and proposed a gravity equation containing multilateral resistance terms $(\mathrm{MRT})^{4}$.

The gravity model is inspired by the basic gravitational equation in Newtonian physics and describes FDI flows between two countries by the size of the two countries (host and source) and the distance between the two. It has good explanatory power as the equations fit well statistically and give quite similar outcomes in many different datasets with varying distances and trade costs (Anderson, 2010). The basic form of the gravity equation is as follows:

$$
T_{i j}=\frac{G D P_{i}^{\alpha} G D P_{j}^{\beta}}{D_{i j}^{\theta}}
$$

where: $T_{i j}$ indicates foreign trade between country $i$, and $j$; GDP $\mathrm{G}_{\mathrm{i}}$ and $\operatorname{GDP}_{\mathrm{j}}$ state the economic size of $\mathrm{i}$ and $\mathrm{j}$ countries, measured by GDP; and $\mathrm{D}_{\mathrm{ij}}$ shows the bilateral distance between the two countries. Anderson (1979), Bergstrand (1985), (1989), and Deardorff (1995) suggest that gravity specification provides convenience in various trade models. Also, many variables considered to affect trade are taken into account in standard gravity models. These variables are geographical distance, cultural distance, colonial link, a common language, and geographic contiguity. The primary gravity approach is frequently applied to study the determinants of bilateral FDI flows. It is assumed that FDI flows are more significant both between large economies and between close neighbouring countries. However, Globerman and Shapiro (1999), Bevan et al. (2004), Zwinkels and Beugelsdijk (2010), and Cuervo-Cazurra (2008) build an augmented gravity model, incorporating several variables (i.e., political stability, cultural distance, and standard language as explanatory variables) to the basic gravity model for analysing the FDI flows. Thanks to these augmented gravity models have been obtained clear empirical findings with high explanatory power. The augmented form of the gravitational equation including the determinants of the FDIs is as follows:

$$
\begin{aligned}
& \operatorname{lnFDI} \mathrm{ijt}_{\mathrm{jt}}=\beta_{0}+\beta_{1} \operatorname{lngdp}_{\mathrm{it}}+\beta_{2} \operatorname{lngdpt}_{\mathrm{jt}}+\beta_{3} \operatorname{lnmig}_{(\text {inflow }) \mathrm{jt}}+\beta_{4} \operatorname{lnmig}_{(\text {oufflow) } \mathrm{jt}}+\beta_{5} \operatorname{lndistance}_{\mathrm{ij}}+ \\
& \beta_{6} \text { lnpolity }_{i t}+\beta{ }_{7} \text { lnpolityt }_{j t}+e_{i j t}
\end{aligned}
$$

Empirical studies detailing the determinants of foreign direct investment consider a wide variety of factors as well as key variables. The control variables considered here are those used in other empirical studies investigating the relationship between migration and FDI. On the one hand, adding the $\operatorname{lnmig}_{(\text {inflow)ijt }}$ and $\operatorname{lnmig}_{(\text {outflow)ijt }}$ variables to the basic gravity model is wanted to take into account the network effect migration on FDIs. On the other hand, the lnpolity ${ }_{i t}$ and lnpolityt ${ }_{j t}$ measures the political stability level is included in the

4 Three alternatives have been proposed in the literature to deal with MRT. First, the multilateral resistance terms are unobserved but can be estimated using fixed-effects Rose and van Wincoop (2001). Second, nonlinear models can be linearized and solved analytically (Anderson van Wincoop, 2003). Third, Baier and Bergstrand (2009) proposed first apply first-order Taylor-series expansion to the multilateral resistance terms, and substitute these in the equation. 
Aksöz-Y1lmaz, H. (2021), "Another Perspective of The Effects of Migration as A Determinant of Foreign Direct Investment: Evidence-Based on Panel Gravity Model from Turkey and OECD Countries”, Sosyoekonomi, 29(50), 169-196.

model, especially following Zwinkels and Beugelsdijk (2010) line, as the political stability of countries is considered that an essential factor in attracting FDIs.

While the theoretical justification of the gravity model is no longer in doubt, its empirical application is controversial. These are particularly relevant to choosing the appropriate estimating method in the presence of zero FDI flows. Initial studies utilized the gravity equation using OLS by dropping all countries for which the sample's FDI and immigration data are not available. The other practice in the literature employed to deal with the problem of zero FDI flows is using censored regression techniques (Tobit). The consistency of the estimates in the Tobit method is questionable due to arbitrarily chosen censoring value (Silva \& Tenreyro, 2006). Keeping the zero observation values in the model with appropriate estimation methods prevents downward bias coefficients. Many authors have encountered problems in consistently estimating the dependent variable's conditional mean using the dependent variable's logarithm when calculating elasticity in logarithmic linear models. Goldberger (1968), Manning and Mullahy (2001), Frankel and Wei (1993) used the nonlinear least squares (NLS) method for estimating multiplicative models. However, the NLS estimator is not effective as it does not take into account heteroskedasticity. It is misleading to interpret the parameters of logarithmic linearized models estimated with OLS as flexibility in the presence of heteroskedasticity. Estimation results are inconsistent in the presence of heteroskedasticity in log-linear models. Because of misleading estimates, constant elasticity models should be estimated in multiplicative form. Therefore, a simple Poisson estimator is recommended due to zero-valued observations. The Poisson PML estimator is simple and reliable to apply in a wide variety of situations. The PPML estimator has the basic features required to estimate the constant elasticity model (Silva \& Tenreyro, 2006: 645). To deal with zero value, Silva and Tenreyro (2006) recommend using the PPML estimator when the data is substantially zero, as it does not assume a normal distribution to provide consistent estimators. They compared the performance of the PPML estimator with that of OLS (in the log-linear specification, employing conventional and the fixed-effects gravity equations) using Monte-Carlo simulations. In models with heteroscedasticity, the estimation results obtained with the help of log models are largely biased, and the obtained coefficient estimates are biased. These biases may mislead policymakers regarding the comparative evaluation of economic theories and evaluating the effects of different policies. When the gravity equation is estimated by a simple pseudo-maximum likelihood (PML) estimation method in multiplier form, it provides an efficient way for estimations that are consistent by keeping the zero values of the dependent variable in the model even if the model has heteroscedasticity (Silva \& Tenreyro, 2006: 649). Burger et al. (2009) disputed that the PPML model is defenceless to overdispersion in the dependent variable and excess zero flows. The PPML method only takes care of observed heterogeneity and unobserved ones. Especially when the number of zero observations is substantial, standard Poisson estimation severely underpredicts these zero observations. Bosker (2008) and Bosker and Garretsen (2010) stated that Poisson estimates suffer from underpredicting the number of zero observations. They proposed the two-stage estimation method when faced with a sample containing a large number of zeros. 
Aksöz-Y1lmaz, H. (2021), "Another Perspective of The Effects of Migration as A Determinant of Foreign Direct Investment: Evidence-Based on Panel Gravity Model from Turkey and OECD Countries”, Sosyoekonomi, 29(50), 169-196.

Helpman et al. (2007) apply the two-stage estimation method to assess countries with zero value trade flows (similar to Heckman selection models). A two-stage estimation is a twostep approach under the normality assumption: first, estimation of the probability of trade with the help of probit regression; second, use the first approach to estimate the volume of trade. Although two-stage estimation provides an avenue of using information from zero trade observation and has a theoretically sound method, it is difficult to satisfy the exclusion restriction because the instrumental variable is often difficult to find (Burger et al., 2009; Brakman et al., 2010) and do not control for heteroscedasticity that is common in the trade and FDI (Flam \& Nordstrom, 2011; Silva \& Tenreyro, 2009). Brakman et al. (2010) preferred the ZINB model instead of the two-stage estimation method, which is difficult to satisfy the exclusion restriction because the instrumental variable is often difficult to find and requires normal distribution in the data. The zero-inflated approach offers a flexible way in practice in the zero FDI flow problem, and it has few restrictions as it does not assume normality as in the Heckman model. The negative binomial regression model is the generalized form of the Poisson model. While the Poisson model submits the restriction that the conditional mean of the dependent variable is equal to its variance, the negative binomial regression model includes the individual unobserved effect in the conditional mean, which allows for overdispersion in the data (Wooldridge, 2002). Zero Inflated Models have good performance as they correct for excessive zeros and excessive distribution in the dependent variables. Zero Inflated Models may be preferred where the observed zero value of the FDI is not greater than the number of zeros predicted by the model.

The reliability of the regression estimation results comes into question because the standard gravity models include non-stationary variables (FDI flows and GDP). It is shown that GDP and FDI data are not stationary in Appendix Table 8. Faruqee (2004) and Fidrmuc (2009) are rare studies that analyse the effect of nonstationary of variables on the results of gravity models based on panel data. On the one hand, the fixed-effects estimator shows the long-run relationship between the gravity variables, including the endogeneity between GDP and FDI flows. On the other hand, the possible bias of studies based on fixed-effects models due to the nonstationary of gravity models is relatively small (Fidrmuc, 2009: 444). Consequently, the fixed-effect PPML estimator was preferred to analyse the effect of migration flows on FDI flows ${ }^{5}$.

\section{The FDI and Migration Data of Turkey-OECD Countries}

This analysis has been carried using a database of 340 observations. This database considers data on annual migration and FDI flows between 20 OECD countries and Turkey over 2003-2019. The OECD includes 37 members. On account of a lack of data on some members, countries with no access to data were excluded from the model. Our purpose is to

\footnotetext{
5 While Model 1 unilaterally accepts FDI flows from OECD countries to Turkey as a dependent variable; Model 2 unilaterally reveals FDI flows from Turkey to OECD countries as a dependent variable. Due to the modelling of unilateral FDI flows between Turkey and OECD countries, it is not necessary to use country fixed effects such as exporter and importer, which Anderson and van Wincoop (2003) state, to control MRT.
} 
determine the impact of the migration flows on FDI flows between OECD countries and Turkey. A great majority of Turkey's inward FDI originates from the OECD countries included. Annual data covering 2003-2019 for the 20 OECD countries (i.e., Australia, Austria, Belgium, Czech Republic, Denmark, Finland, Germany, Hungary, Iceland, Italy, Japan, South Korea, Luxembourg, Netherlands, New Zealand, Norway, Slovakia, Spain, Sweden, Switzerland) are utilized in this study.

Turkey's inward and outward FDI amount is shown in graph 1-2. According to this, Turkey's total inward FDI amount was 1,702 million dollars in 2003; it reached 22.047 million dollars in 2008. However, it decreased significantly after 2008 with the impact of the global economic crisis. While Turkey's total inward foreign direct investments were realized as 12,981 million dollars in 2018, this amount decreased to 8,344 million dollars in 2019 due to the effect of global pandemic conditions. Turkey's total outward FDI amount was 480 million dollars in 2003; it was 2.549 million dollars in 2008. With the effect of the global crisis, it started to decrease after 2008. While Turkey's total outward foreign direct investments were realized at the level of 6,682 million dollars in 2014, this amount decreased to the level of 2008 with 2,841 million dollars in 2019 due to the effect of global pandemic conditions. Turkey's percentage share of inward and outward FDI in the entire world is shown in graph 2. Turkey's inward FDI rate increased from $0.30 \%$ to $1.4 \%$ between 2003 2006 years. Although the inward FDI ratio decreased after 2008 due to the global economic crisis, it generally increased until 2016. Turkey's inward FDI rate has always been higher than the outward FDI rate when examined as covering the years 2003-2019 periods.

Graph: 1

Turkey's Total Inward FDI and Outward FDI

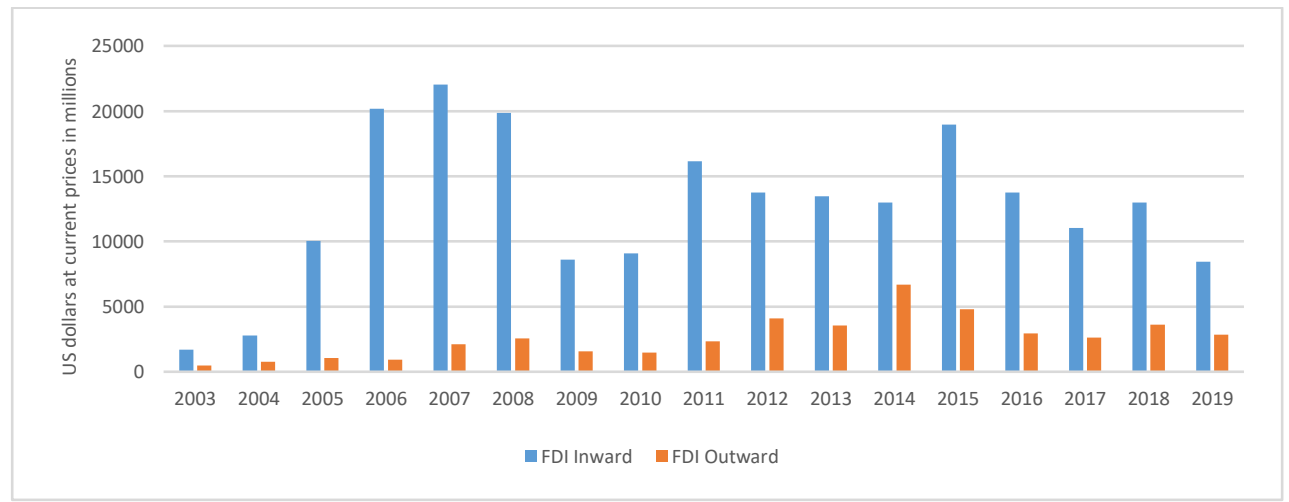

Source: UNCTAD Database.

OECD countries make most of the total inward FDI to Turkey (Appendix Table 6 and 7). Although the group of OECD countries has the highest share in Turkey's total inward FDI positions, the European countries group has the highest share in total outward FDI positions. Given the impact and volume of FDI positions on the country's economy, it seems 
reasonable to include the OECD country group, which realizes the highest inward FDI flows to Turkey, within the scope of the study.

\section{Graph: 2 \\ Turkey's Percentage Share of Inward and Outward FDI in World}

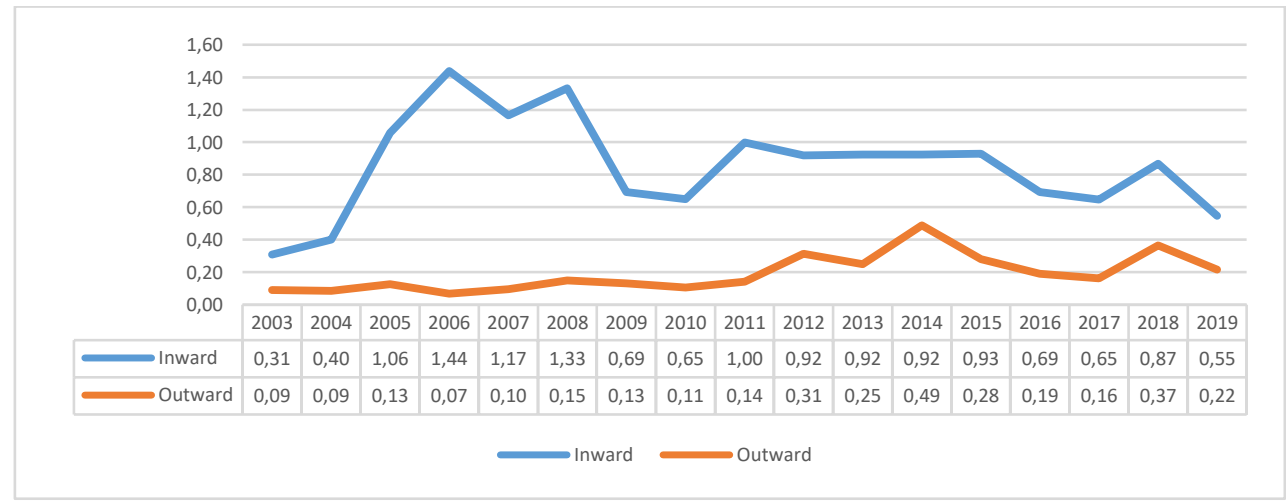

Source: UNCTAD Database.

In the migration from Turkey to other countries, developed countries are mostly preferred as destination countries. Due to its geographical location, Turkey is a transit country between underdeveloped and developed countries. "Historically, Turkey has been a country of origin, transit, and destination for migrants and was a crossroads between Europe and Asia. Recent regional events have contributed to Turkey increasingly becoming a major destination and transit country for those fleeing conflict, poverty, and disasters" (IOM, 2021). In this sense, it is difficult to distinguish the effects of migration flows to Turkey as a destination country and migration flows to Turkey for transition to developed countries. When the migrants who left their countries due to war and political turmoil and took refuge in Turkey are not considered, there is a heavy volume of migration between OECD countries and Turkey as the destination and source country in the migration flows. In 1990, the stock of Turkish immigrants in the world was 2.512.944, including 1.349.675 males and 1.163.269 females. Germany is one of the countries hosting the most extensive Turkish immigrant stock. At the beginning of 1960, many workers migrated from Turkey to Germany to meet the labor demand of Western Europe and especially Germany. Although the workers who went to Germany with the government's approval aimed to return to their homeland, they did not tend to return afterward. With the family reunification and the increase of the immigrant network over time, there have been significant migration flows to Western Europe, especially Germany. As of 2020, the total stock of Turkish immigrants in Germany was 1,476,410 people (OECD.stat, 2021). The total stock of Turkish immigrants worldwide is 3.411.408, including 1.766.026 males and 1.645.382 females (IOM, 2021). Since OECD countries host more than half of the total Turkish immigrant stock in the World. In 2019, the highest immigration flowed from Turkey to OECD countries were Germany, the United 
States, France, and Austria. The highest immigration flows from OECD countries to Turkey were Germany, Austria, the Netherlands, and Japan (OECD.stat, 2021).

\section{Graph: 3}

\section{The FDI and Migration Flows by Years for 20 OECD Countries}
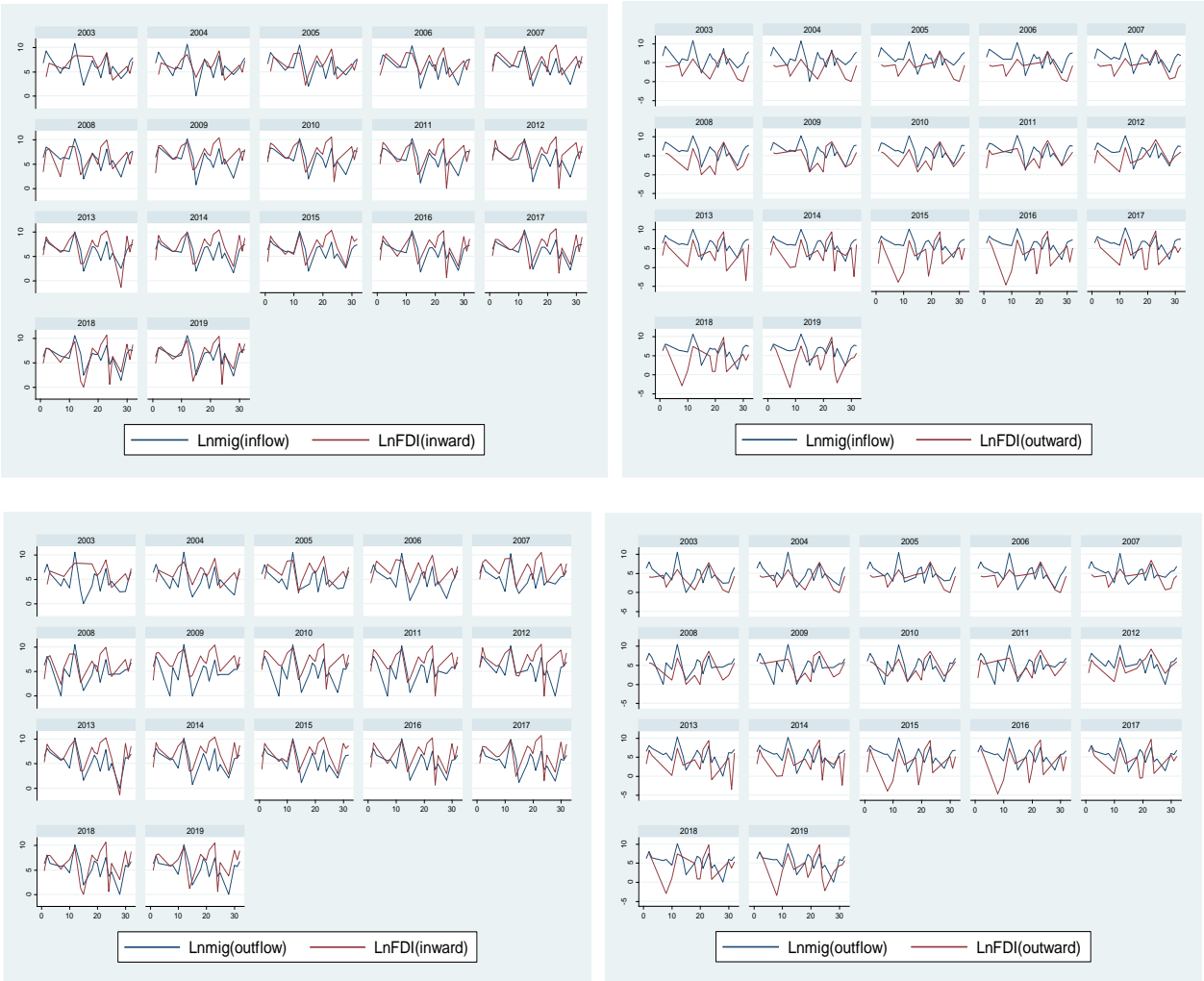

While the volume of free capital movements increased with globalization after 1980, as in the whole world, migration mobility has increased with the contribution of transportation and technological developments in Turkey, migration flows have a wide range of effects on destination and source countries. One of the deviational contributions of migration flows is that it affects investment relations between source and destination countries. When people migrate from one country to another, besides their labour and capital, they also bring in a social network connected to their home country. These social networks play a leading role in reducing barriers to international investment, such as political risk and asymmetric information (Foad, 2012: 238). Therefore, immigrants are a bridge in which capital can move more easily between their homeland and current countries. It is shown the relationship between migration flows and foreign direct investments for Turkey 
and OECD countries by years and by countries in Graph 3. It is seen that migration flows from Turkey to the OECD and Turkey's inward FDI tend to act together in the period covering the years 2003-2013, especially in 2005, 2014, 2015, 2017, 2018, and 2019 years. If the trend of Turkey's outward FDI (to OECD) and the immigrant flows between Turkey and OECD countries (inflow and outflow) is followed, it is difficult to say that they exhibit a similar trend. Let's examine the trend of FDI and immigrant flows in the period between 2003-2019 of the countries in the panel. These two variables tend to act together for Belgium, Denmark, Germany, Japan, and the Netherlands.

\section{Graph: 4}

\section{The FDI and Migration Flows by the Country for the Years 2003-2019}
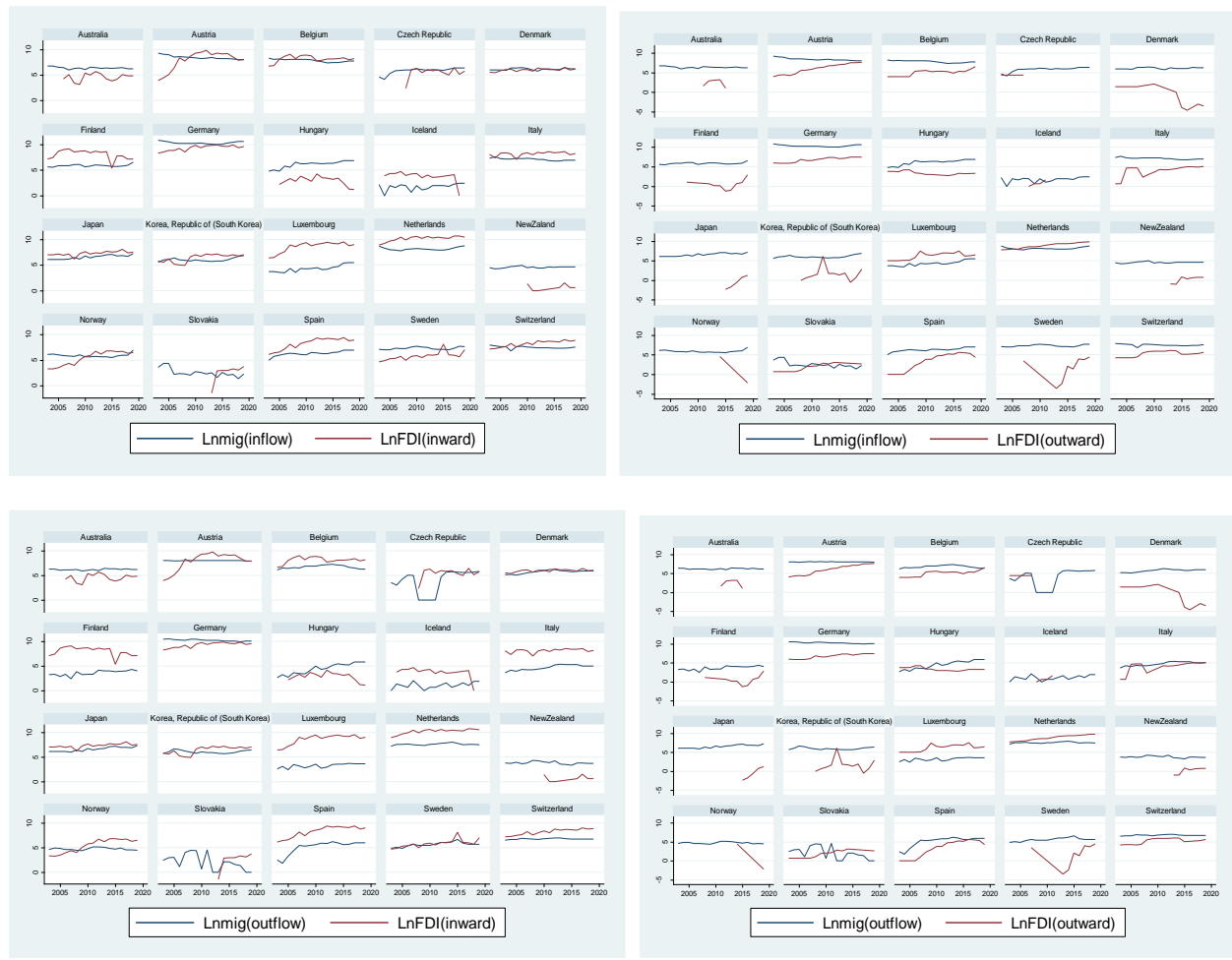

The variables in this study consist of outward and inward FDI positions (FDI positions measured in US\$ Millions), per capita GDP (GDP measured in constant 2010 US\$), distance (geographical distance measured in between the most populated cities of 20 OECD countries and Istanbul), polity Score (Polity measured in ranges from -10 to +10 ), inflow and outflow migration (total inflow migration from Turkey to OECD countries and total outflow migration from Turkey to OECD countries). This study used total inflow 
migration, outflow migration, per capita GDP, distance, and polity score in natural logarithm form as independent variables; total inward FDI and outward FDI in level as dependent variables. The outward and inward FDI data, per capita GDP, inflow, and outflow migration is collected from the Organisation for Economic Co-operation and Development (OECD) databank. The data on distance is collected from the CEPII database, and the data on polity score is obtained from the Integrated Network for Societal Conflict Research (INSCR).

Table: 1

\section{Explanation of Variables and Data Sources}

\begin{tabular}{|c|c|}
\hline Variables & Explanation \\
\hline Inpolity (INSCR) & Polity Score measured in ranges from -10 to +10 in OECD countries, in natural logarithm form (log) \\
\hline lnpolityt (INSCR) & Polity Score measured in ranges from -10 to +10 in Turkey, $(\log )$ \\
\hline $\operatorname{lngdp}(\mathrm{OECD})$ & Per Capita Gross Domestic Product (constant 2010 US\$) in OECD countries, (log) \\
\hline lngdpt (OECD) & Per Capita Gross Domestic Product (constant 2010 US\$) in Turkey, (log) \\
\hline lndistance (CEPII) & The geographical distances $(\mathrm{km})$ between the source and host countries, $(\log )$ \\
\hline $\operatorname{lnmig}_{\text {inflow }}(\mathrm{OECD})$ & Total inflow migration from Turkey to OECD countries, (log) \\
\hline $\operatorname{lnmig}_{\text {outflow }}(\mathrm{OECD})$ & Total outflow migration to Turkey from OECD countries, (log) \\
\hline $\mathrm{FDI}_{\text {inward }}(\mathrm{OECD})$ & Total inward FDI flows to Turkey to OECD countries \\
\hline $\mathrm{FDI}_{\text {outward }}(\mathrm{OECD})$ & Total outward FDI flows from Turkey to OECD countries \\
\hline lan & Dummy variable $=1$ if OECD countries have a common official language; 0 otherwise \\
\hline eu & Dummy variable $=1$ if OECD countries are the member of the Europe Union; 0 otherwise \\
\hline
\end{tabular}

\section{Models and Results}

In this study, $\mathrm{FDI}_{\text {(inward)ijt }}$ and $\mathrm{FDI}_{\text {(outward)ijt }}$ represent dependent variables; inward and outward FDI flows between the source countries i (i.e., 20 OECD countries) and the destination country $\mathrm{j}$ (Turkey) using data spanning the period (2003-2019). GDP per capita of Turkey $i$ and the OECD countries $j$ in year $t$ has been expressed by lngdp $\mathrm{it}_{\mathrm{i}}$ and lngdpt $\mathrm{t}_{\mathrm{j}}$, respectively. The polity score of Turkey $\mathrm{i}$ and the OECD countries $\mathrm{j}$ in year $\mathrm{t}$ has been indicated by lnpolity $y_{i t}$ and lnpolityt $\mathrm{j}_{\mathrm{j}}$, respectively. The immigrant flows to OECD countries

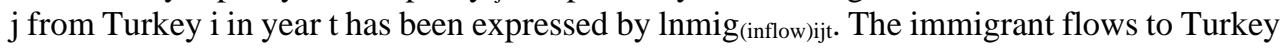

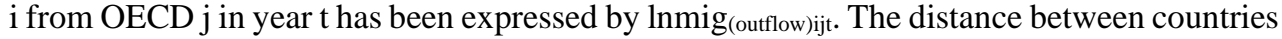
$\mathrm{i}$ and $\mathrm{j}$ have been shown by lndistance $\mathrm{e}_{\mathrm{ij}}$, and $\varepsilon_{\mathrm{ijt}}$ is the error term. The gravity model (inward FDI Model) is formulated as:

Inward FDI Model 1: FDI $\left(\right.$ inward)ijt $=\beta_{0}+\beta_{1} \operatorname{lngdp}_{\mathrm{it}}+\beta_{2} \operatorname{lngdpt}_{\mathrm{jt}}+\beta_{3} \operatorname{lnmig}_{(\mathrm{inflow}) \mathrm{jit}}+\beta_{4} \operatorname{lndistance}_{\mathrm{ij}}$

$+\beta 5$ Inpolity ${ }_{i t}+\beta 6$ lnpolityt $_{\mathrm{j} t}+\mathrm{e}_{\mathrm{ijt}}$

Inward FDI Model 2: FDI (inward)ijt $=\beta_{0}+\beta_{1} \operatorname{lngdp}_{\mathrm{it}}+\beta_{2} \operatorname{lngdpt}_{\mathrm{jt}}+\beta_{3} \operatorname{lnmig}_{(\text {outflow)ijt }}+$ $\beta_{4} \operatorname{lndistance}_{\mathrm{ij}}+\beta_{5}$ lnpolity $_{\mathrm{it}}+\beta_{6}$ lnpolityt $_{\mathrm{jt}}+\mathrm{e}_{\mathrm{ijt}}$

Table 2 states ZINB regression and PPML estimation results for inward FDI model 1 and inward FDI model 2. 
Aksöz-Y1lmaz, H. (2021), "Another Perspective of The Effects of Migration as A Determinant of Foreign Direct Investment: Evidence-Based on Panel Gravity Model from Turkey and OECD Countries”, Sosyoekonomi, 29(50), 169-196.

Table: 2

ZINB and PPML Estimates

\begin{tabular}{|c|c|c|c|c|c|c|}
\hline \multirow{2}{*}{ Variables } & \multicolumn{3}{|c|}{ ZINB } & & \multicolumn{2}{|c|}{ PPML } \\
\hline & \multicolumn{2}{|c|}{ Active Category } & \multicolumn{2}{|c|}{ Passive Category } & & \\
\hline$F_{\text {FDI }}$ inward & \multicolumn{2}{|c|}{ Negative Binomial } & \multicolumn{2}{|c|}{ Logit } & & \\
\hline \multirow[t]{2}{*}{ Inpolity } & 1.156 & 0.931 & $11.258^{* * *}$ & $12.580^{* * * *}$ & $1.726^{* * *}$ & $1.806 * *$ \\
\hline & (1.157) & $(1.169)$ & $(4.778)$ & $(4.950)$ & $(0.773)$ & $(0.846)$ \\
\hline \multirow{2}{*}{ Inpolityt } & $1.901^{*}$ & 0.477 & -4.049 & -3.399 & 1.835 & 1.187 \\
\hline & $(1.103)$ & $(1.121)$ & $(3.772)$ & $(3.652)$ & $(1.357)$ & $(1.334)$ \\
\hline \multirow[t]{2}{*}{ lnmig $_{\text {inflow }}$} & $0.622 * * *$ & & $-0.650 * * *$ & & $0.449^{* * * *}$ & \\
\hline & $(0.051)$ & & $(0.144)$ & & $(0.032)$ & \\
\hline \multirow[t]{2}{*}{ lnmig outflow } & & $0.400 * * *$ & & $-0.455^{* * *}$ & & $0.347 * * *$ \\
\hline & & $(0.040)$ & & $(0.126)$ & & $(0.024)$ \\
\hline \multirow[t]{2}{*}{ Indistance } & $-0.364 * *$ & $-0.942 * * * *$ & $1.223^{* * * *}$ & $1.326^{* * * *}$ & $-0.274 * * *$ & $-0.441 * * *$ \\
\hline & $(0.164)$ & $(0.153)$ & $(0.318)$ & $(0.300)$ & $(0.073)$ & $(0.071)$ \\
\hline \multirow[t]{2}{*}{ lngdp } & $2.147^{* * * *}$ & $1.582 * * *$ & $-7.313^{* * * *}$ & $-7.093 * * *$ & $1.851^{* * * *}$ & $1.710 * * *$ \\
\hline & $(0.276)$ & $(0.294)$ & $(1.473)$ & $(1.349)$ & $(0.214)$ & $(0.196)$ \\
\hline \multirow[t]{2}{*}{ lngdpt } & $-1.099 *$ & -0.491 & -0.050 & -0.128 & -0.455 & -0.236 \\
\hline & $(0.641)$ & $(0.636)$ & $(2.210)$ & $(2.125)$ & $(0.626)$ & $(0.647)$ \\
\hline \multirow[t]{2}{*}{ Constant } & $-11.911 * *$ & -1.986 & $50.498^{* * * *}$ & $-42.453 * *$ & $-15.805^{* * *}$ & $-12.981 * * *$ \\
\hline & (5.889) & $(5.653)$ & (18.115) & $(17.732)$ & $(4.727)$ & (4.984) \\
\hline Observation & 340 & 338 & 340 & 340 & 340 & 338 \\
\hline Pseudo $\mathrm{R}^{2}$ & & & & & 0.46 & 0.44 \\
\hline
\end{tabular}

Note: Dependent variables is $F D I_{\text {inward, }} *^{* *} p<0.01$, $*^{*} p<0.05, *_{p}<0.1$, Robust standard errors clustered in parentheses.

ZINB and PPML estimators show the gravity model results established to reveal the effect of Turkey-OECD migrant flows on inward FDI to Turkey from OECD countries. Except for the lnpolity variables, the same characteristics for both groups in the ZINB model. The signs for these variables are often opposite, which makes logical and consistent with a priori expectation. The estimation results for the Active Group in Table 2 show that typical gravity variables and migrant flows variables help explain FDI flows between countries. A country's political stability impacts FDI flows as it can generate transaction costs (Leibrecht \& Riedl, 2013). While Turkey's political stability has a positive impact on inward FDI to Turkey from the OECD, the political stability of OECD countries is not significant on inward FDI to Turkey from OECD. The GDP variable used to measure the market size has different effects for source and target countries. While Turkey's GDP variable has a negative effect, OECD countries' GDP variable has a positive effect on FDI flows. If countries are geographically distant, this can increase monitoring and investment costs (Leibrecht \& Riedl, 2013: 1215). The negative sign of the distance variable is consistent with this line of reasoning. That is, the lower the distance, the higher the FDI flows. In addition to the higher coefficient of migrant flows from Turkey to OECD countries, both the immigrant flows from Turkey to the OECD countries and from the OECD countries to Turkey positively affect inward FDI to Turkey from the OECD country. When faced with a sample with many zeros, Bosker and Garretsen (2010) recommend the two-stage estimation method, while Brakman et al. (2010) suggested a zero-inflated approach. In the data of inward FDI to Turkey from OECD countries, 35 of 340 observations have a zero value. That is, the zero-observation value in the sample is about $10 \%$. In this case, Burger (2009), Brakman et al. (2009), and Bosker and Garretsen (2010) statements about the importance of the number of zero-value observations are instructive at the point of preferring the results of the PPML estimation method instead of the ZINB estimator. Hence, Silva and Tenreyro (2011) argue that the 
PPML estimator performs well even with overdistribution and large zero values in the dependent variable. Therefore, it would be appropriate to consider the PPML estimation results. Although the PPML estimation results are similar to the ZINB estimation results in terms of the significance of the variables except for the political stability of the destination and source countries, the coefficients obtained from the PPML estimator are lower than the ZINB estimation results. The coefficients on lnpolity are positive (1.72 and 1.80), suggesting that the political stability of OECD countries significantly increases inward FDI to Turkey from the OECD. The immigrant flows between Turkey and OECD have a positive effect on inward FDI to Turkey from OECD, and the immigrant flows from Turkey to OECD countries are more effective on inward FDI to Turkey. In other words, a $1 \%$ increase in the immigrant flows to OECD from Turkey will correspond to an increase in inward FDI to Turkey from OECD of $0.44 \%$. This finding is similar to Gao's (2003) and Tong (2005) findings that stated that the FDI stock increases by $6.2 \%$ when the population share of ethnic Chinese in the source country increases by $1 \%$ point. It should be noted that comparing the coefficients of Gao (2003) and our study would not be an accurate interpretation. Although FDI flows were considered in our study, Gao (2003) focused on FDI stock. However, we should say that Gao (2003) and our study revealed similar findings. Also, Tong (2005) highlighted that the magnitude of the estimates on ethnic Chinese is larger for FDI from industrial countries (0.28) than for FDI from developing countries (0.15). There are almost the same our coefficient $(0.44)$ and Tong (2005)' coefficient $(0.15+0.28=0.43)$. A $1 \%$ increase in the immigrant flows from OECD to Turkey will correspond to an increase in inward FDI to Turkey from OECD of $0.34 \%$. Likewise, Buch et al. (2006) find that German states with a large foreign population from the same country of origin have more stocks of FDI. In addition to the fact that the distance between countries negatively affects FDI flows, the PPML estimation results show that distance has a smaller effect on FDI flows than the ZINB estimation results. The coefficients on distance are negative ( -0.27 and -0.44$)$ and, advising that the distance between Turkey and OECD countries significantly decreases inward FDI to Turkey from OECD. The GDP of OECD countries is significant on FDI flows, and its coefficient is the highest compared to the coefficients of other variables. Though political stability and GDP are attractive factors for FDIs, these variables have not been found to impact FDIs inward to Turkey. In the present case, examining the effectiveness of other economic and diplomacy channels between Turkey and OECD countries will provide us with new ideas.

Outward FDI Model 1: FDI (outward)ijt $=\beta_{0}+\beta_{1} \operatorname{lngdp}_{\mathrm{it}}+\beta_{2} \operatorname{lngdpt}_{\mathrm{jt}}+\beta_{3} \operatorname{lnmig}_{\text {(inflow)ijt }}+$ $\beta_{4}$ Indistance $_{i j}+\beta_{5}$ Inpolity $_{i t}+\beta_{6}$ lnpolityt $_{j t}+\mathrm{e}_{\mathrm{ijt}}$

Outward FDI Model 2: FDI $_{(\text {outward)ijt }}=\beta_{0}+\beta_{1} \operatorname{lngdp}_{\mathrm{it}}+\beta_{2} \operatorname{lngdpt}_{\mathrm{jt}}+\beta_{3} \operatorname{lnmig}_{(\text {ourflow) ijt }}+$ $\beta_{4}$ Indistance $_{i j}+\beta_{5} \operatorname{lnpolity}_{i t}+\beta_{6} \operatorname{lnpolityt}_{\mathrm{jt}}+\mathrm{e}_{\mathrm{ijt}}$

The zero-inflated model assumes that there are two latent groups of observations (active and passive). The definition of an active and passive group is given by Brakman et al. (2010) as follows: 
"...an observation in the (always 0) Passive Group has an outcome of 0 with a probability of 1; an observation in the (potentially) Active Group might have a zero outcome, but there is a positive probability that there is a non-zero outcome.."

Table 3 presents the Zero Inflated Negative Binomial regression and PPML estimation results for the outward FDI model 1 and outward FDI model 2. The columns related to the active group give estimates for the group for which the observations are not necessarily zero; the columns concerning the passive group give estimates for the alwayszero group of observations.

Table: 3

ZINB and PPML Estimates

\begin{tabular}{|c|c|c|c|c|c|c|}
\hline \multirow[b]{2}{*}{ Variables } & \multicolumn{3}{|c|}{ ZINB } & & \multicolumn{2}{|c|}{ PPML } \\
\hline & \multicolumn{2}{|c|}{ Active Category } & \multicolumn{2}{|c|}{ Passive Category } & & \\
\hline FDI outward & \multicolumn{2}{|c|}{ Negative Binomial } & \multicolumn{2}{|c|}{ Logit } & & \\
\hline \multirow[t]{2}{*}{ lnpolity } & $-4.293 * *$ & -2.903 & 2.794 & 2.780 & 6.062 **** & $6.187 * * *$ \\
\hline & $(2.149)$ & (2.039) & (2.317) & $(2.321)$ & $(1.401)$ & $(1.576)$ \\
\hline \multirow[t]{2}{*}{ Inpolityt } & $7.857 * * *$ & 6.554 & -0.748 & -0.548 & 3.211 & 2.150 \\
\hline & (1.956) & (1.883) & $(2.028)$ & (2.064) & (2.789) & (2.811) \\
\hline \multirow[t]{2}{*}{$\operatorname{lnmig}_{\text {inflow }}$} & $0.683^{* * * *}$ & & $-0.334 * * *$ & & $0.614 * * *$ & \\
\hline & $(0.062)$ & & $(0.076)$ & & $(0.061)$ & \\
\hline \multirow[t]{2}{*}{ Inmig ${ }_{\text {outflow }}$} & & $0.652^{* * * *}$ & & $-0.330^{* * * *}$ & & $0.488^{* * * *}$ \\
\hline & & $(0.054)$ & & $(0.069)$ & & $(0.040)$ \\
\hline \multirow{2}{*}{ Indistance } & $-0.957 * * *$ & $-1.133 * * *$ & $1.669 * * *$ & $1.835 * * *$ & -0.140 & $-0.324 * * * *$ \\
\hline & $(0.237)$ & $(0.232)$ & $(0.426)$ & $(0.439)$ & $(0.111)$ & $(0.105)$ \\
\hline \multirow[t]{2}{*}{ lngdp } & $3.159 * * *$ & $2.890 * * *$ & -0.226 & -0.185 & 2.603 **** & $2.489 * * *$ \\
\hline & $(0.376)$ & $(0.342)$ & $(0.451)$ & $(0.456)$ & $(0.320)$ & $(0.272)$ \\
\hline \multirow[t]{2}{*}{ lngdpt } & $-3.250 * * *$ & $-2.562 * * *$ & -1.055 & -0.966 & -0.061 & 0.420 \\
\hline & $(1.052)$ & $(0.973)$ & (1.090) & (1.102) & (1.407) & $(1.523)$ \\
\hline \multirow[t]{2}{*}{ eu } & $2.036^{* * * *}$ & $2.022 * * *$ & 0.913 & 0.799 & & \\
\hline & $(0.337)$ & $(0.336)$ & (0.593) & (0.590) & & \\
\hline \multirow[t]{2}{*}{ lan } & & & $-1.131 *$ & $-1.311^{* * *}$ & & \\
\hline & & & $(0.670)$ & $(0.678)$ & & \\
\hline \multirow[t]{2}{*}{ Constant } & -1.378 & -3.672 & -4.587 & -7.877 & $-45.011^{* * * *}$ & $-43.904 * * *$ \\
\hline & $(7.295)$ & (6.794) & (9.775) & $(9.788)$ & (10.854) & (11.552) \\
\hline Observation & 340 & 338 & 340 & 340 & 340 & 338 \\
\hline Pseudo $\mathrm{R}^{2}$ & & & & & 0.41 & 0.40 \\
\hline
\end{tabular}

Note: Dependent variables is $F D I_{\text {outward }}, * * p<0.01, * * p<0.05, * p<0.1$, Robust standard errors clustered in parentheses.

The estimation results of these models based on the ZINB and PPML method address the impact of immigrant flows between Turkey and OECD on outward FDI from Turkey to the OECD. The outward FDI model 1 and outward FDI model 2 have 340 FDI flow data, 107 of which have a zero-value observation. The number of zero flows constitutes approximately $32 \%$ of the total number of observations in the sample. In this case, Burger et al. (2009), Bosker and Garretsen (2010), and Brakman et al. (2010) mentioned in their study, especially when the number of zero observations is substantial, standard Poisson estimation severely underpredicts these zero observations. The estimation results of the ZINB model gain importance as becomes stronger the probability of underperforming the PPML estimator in such samples. ZINB model results reveal that the political stability of the destination country has a significant and negative effect on FDI flows. On the other hand, 
Aksöz-Y1lmaz, H. (2021), "Another Perspective of The Effects of Migration as A Determinant of Foreign Direct Investment: Evidence-Based on Panel Gravity Model from Turkey and OECD Countries”, Sosyoekonomi, 29(50), 169-196.

political stability in Turkey also has a positive effect on outward FDI from Turkey to OECD countries.

While the GDP of the destination countries positively affects the outward FDI from Turkey to OECD countries, Turkey's GDP has a negative impact on FDI flows ${ }^{6}$. When Turkey's GDP increases, there is a decrease in outward FDI flows from Turkey to OECD countries due to domestic investors' inclination towards domestic investments. Although the importance of distance between countries for FDI flows is not as obvious as trade, it emphasizes costs such as monitoring countries' investment opportunities. Consistent with theoretical expectations, the distance between Turkey and OECD countries negatively affects the outward FDI from Turkey to OECD countries. While the immigrant flows between Turkey and OECD countries positively affect the outward FDI from Turkey to OECD countries, migrant flows from Turkey to OECD are higher than that of immigrant flows from OECD to Turkey. A $1 \%$ increase in the immigrant flows from Turkey to OECD will correspond to an increase in outward FDI from Turkey to OECD of $0.68 \%$. This finding majorly coincides with the reality that those who want to become immigrants in developed countries have to take FDI to their destination countries. A $1 \%$ increase in the immigrant flows from OECD to Turkey will correspond to an increase in outward FDI from Turkey to OECD of $0.65 \%$. Bhattacharya and Groznik (2008), Ligthart and Singer (2009), and Javorcik et al. (2011) have emphasized that immigrants provide FDI flows from receiving countries to their home countries. This finding is quite parallel to the finding of Bhattacharya and Groznik (2008) that U.S. investments in a foreign country are positively affected by the size of the foreign-origin group from that country living in the U.S. Javorcik et al. (2011) also highlighted the result that is in line with our finding. Javorcik et al. (2011) also highlighted the results that are in line with our finding by stating that the outward FDI flows from the U.S. are correlated with migrants from the host country. Along the same line, this finding is consistent with Ligthart and Singer (2009)' finding that immigrant flows are significant in facilitating outward FDI to their countries of origin.

\section{Conclusion}

In this paper, two different models were used for the direction of FDI flows. The most important feature that distinguishes these models from each other is the execution of different estimation techniques. First, the impact of migration on inward FDI flows was analysed with the gravity model based on the PPML estimation method. Second, the analysis of the impact of migration on outward FDI flows was estimated with the ZINB estimation method. To decide which of the PPML and ZINB estimation results are considered valid was taken into account in the density of zero-valued observations in the sample. We consider the ZINB estimation results in the outward FDI models since the ratio of zero-valued observations to the total observations is $32 \%$. For this rate of $10 \%$ in the inward FDI models,

6 While the PPML estimation results confirm the positive effect of target countries' GDP on FDI flows, the effect of Turkey's GDP is insignificant on the outward FDI from Turkey to OECD countries. 
Aksöz-Y1lmaz, H. (2021), "Another Perspective of The Effects of Migration as A Determinant of Foreign Direct Investment: Evidence-Based on Panel Gravity Model from Turkey and OECD Countries”, Sosyoekonomi, 29(50), 169-196.

the PPML estimation results are binding. Estimation results in all models showed that the impact of immigrant flows and distance is significant on FDI flows.

Distance between countries has a negative effect on FDI flows. It is thought that as the distance between the countries increases, its bilateral FDI flows decrease. In this case, it might be said that the increase in the costs of examining investment opportunities reduces FDI flows between countries. Empirical findings show that migrant flows between Turkey and OECD positively affect both inward and outward FDIs between OECD countries and Turkey. The results show that the immigrant flows to OECD from Turkey are relatively more sensitive to the immigrant flows to Turkey from OECD. It should be clearly stated that the most significant impact is the positive effect of immigrants from Turkey to OECD countries on the outward FDI from Turkey to OECD countries. In terms of immigrants' impact on FDI flows, the most negligible impact is seen in the impact of OECD immigrants on inward FDI to Turkey. The effect of immigrant flows on FDI flows more clearly observed in Turkey's outward investments. Although immigrants from Turkey to OECD are increasing their investments from receiving countries to their homeland, they affect more the investments from their homeland to receiving countries through formal channels. Suppose the movement of Turkish citizens to the destination country (more developed OECD countries) depends on their investment in the destination country. In that case, it can be considered effective formal channels between immigration and outward FDI. Hence, according to the Ankara Agreement (starting in 1963 and ending on January 1, 2021), the U.K. government offered residence and work permits when Turkish citizens established a company in the U.K. Turkish immigrants who want to obtain residence and work permits in developed countries have to invest a certain amount in these countries according to the legal regulations of the relevant country. Turkish immigrants who want to benefit from developed countries' social and economic opportunities increase investments from Turkey to OECD countries through this formal channel. The finding that immigrant flows from Turkey to the OECD significantly affect Turkey's outward investments is an accurate finding due to the effectiveness of formal channels.

The results confirm the hypothesis that "the immigrant flows between Turkey and OECD countries positively affect the inward and outward FDI between Turkey and OECD countries over the period 2003-2019". International factor mobility consists of international migration, and capital flows are one of the most important features of the integrated global economy. When immigration and FDI are taken together, international investment channels and migration routes form a complex network of relations between countries. It is a remarkable finding that OECD immigrants coming to Turkey attract high amounts of FDI to their home countries. This information shows that OECD immigrants influence FDI flows through the network channel.

Moreover, immigrants from Turkey to OECD countries attract less FDI to their homeland. In this case, to improve the current balance of payments and meet the Turkish economy's foreign exchange need, it should be ensured that immigrants from Turkey to OECD countries attract more FDI to their homeland. Our recommendation is never policy 
Aksöz-Y1lmaz, H. (2021), "Another Perspective of The Effects of Migration as A Determinant of Foreign Direct Investment: Evidence-Based on Panel Gravity Model from Turkey and OECD Countries”, Sosyoekonomi, 29(50), 169-196.

implementations to reduce outward FDI from Turkey to OECD countries. On the contrary, FDI flows between OECD and Turkey need to be improved. However, more attempts should be made to increase inward FDI to Turkey from OECD countries. In Turkey's 11th Development Plan, primarily foreign direct investments are aimed to be directed to the industrial sector and increase the share of new investments. Although the slowdown trend brought about by the environment of uncertainty due to be on decline global economy and the Covid-19 pandemic can be perceived as a threat, Turkey has jumped up ten places to be 33rd among 190 nations in the World Bank's 2020 Ease of Doing Business Index. It is also important to evaluate the effect of migration on the FDI flows at the point of directing new investments. Besides, the increasing migration with globalization becomes an important element of the labour supply. Policymakers should consider the positive impact of migration on inward FDI to Turkey. Keeping network channels open through individual and corporate organizations with outgoing immigrants from Turkey will increase the inward FDI for the ultimate economic goals of Turkey. These results imply that network developer policies can be pushed to the forefront to receive further FDI flows from OECD countries to Turkey. Network developer policies inform immigrants about investment opportunities by activating individual and institutional channels with their homeland, primarily verbal and written promotional activities that encourage individuals with investor and entrepreneurial potential to immigrate to Turkey. OECD countries with a high migrant flow from Turkey can be provided with cost-reducing facilities in their investments.

One of the most important results of this study is that although immigrants from Turkey to OECD are increasing their investments from receiving countries to their homeland, they affect more the investments from their homeland to receiving countries through the formal channel. We attach great importance to this finding for two reasons. First, our findings mostly coincide with the fact that the number of Turkish citizens who want to live and work in OECD member countries has increased recently. Second, much of the current debate revolved around the network channel, but our study revealed that an obligatory formal channel could be active on the relationship between immigration and FDI. Our study offers an analysis that has not been done previously, revealing the link between FDI and migration for Turkey and OECD countries. Also, there is an area for further development of this analysis. In particular, we recommend a detailed analysis of its effect on FDI flows by using disaggregated immigrant data. This can provide more insight into the relationship between migration and FDI. Finally, the concentrate on the current paper was placed on the influence of the immigration flows on inward and outward FDI between Turkey and OECD countries. Thus, examining how the immigrant flows affect the inward FDI to Turkey from Turkic Republics with historical ties or countries with free trade agreements could provide us with policy recommendations.

Moreover, the results obtained in this study say nothing inevitable about what informal barriers lead to the role of inward and outward FDI to Turkey. However, GDP, political stability, and immigration flows are used to explain FDI flows. A more thorough analysis of this would be worth the effort. 
Aksöz-Y1lmaz, H. (2021), "Another Perspective of The Effects of Migration as A Determinant of Foreign Direct Investment: Evidence-Based on Panel Gravity Model from Turkey and OECD Countries”, Sosyoekonomi, 29(50), 169-196.

\section{References}

Akkoyunlu, Ş. (2010), “Can Trade, Aid, Foreign Direct İnvestments and Remittances Curb Migration from Turkey?", Migration Letters, 7(2), 144-158.

Alfaro, L. \& M. Chen, (2010), "Surviving the Global Financial Crisis: Foreign Direct Investment and Establishment Performance", Harvard Business School Working Paper, No. 10/110.

Ali, S. \& W. Guo (2005), "Determinants of FDI in China", Journal of Global Business and Technology, 1(2), 21-33.

Anderson, J.E. \& E. Van Wincoop (2003), "Gravity with Gravitas: A Solution to the Border Puzzle", American Economic Review, 93(1), 170-192.

Anderson, J.E. (1979), “A theoretical Foundation for Gravity Equation”, American Economic Review, 69(1), 106-116.

Asiedu, E. (2002), "On the Determinants of Foreign Direct Investment to Developing Countries: Is Africa Different?", World Development, 30(1), 107-119.

Baier, S.L. \& J.H. Bergstrand (2007), "Do Free Trade Agreements Actually Increase Members' International Trade?", Working Paper, No. 2005-3, Federal Reserve Bank of Atlanta.

Bal, H. \& E.E. Akça (2016), "Doğrudan Yabancı Sermaye Yatırımlarının Belirleyicileri: Seçilmiş Doğu Asya ve Pasifik Ülkelerinden Ampirik Bulgular”, Sosyoekonomi, 24(30), 91-112.

Barry, F. (2002), "E.U. Accession and FDI flows to CEE countries: Lessons from the Irish Experience", in: Conference on Foreign Direct Investment in the Real and Financial Sector of Industrial Countries, Bundesbank Eltville am Rhein.

Bellino, A. \& G. Celi (2016), "The Migration-Trade Nexus in Presence of Vertical and Horizontal Product Differentiation”, Discussion Paper, No. 137: University of Foggia.

Bergeijk, P.A.G. \& S. Brakman (2010), “The Comeback of the Gravity Model”, in: P.A. Van Bergeijk \& S. Brakman (eds.), The Gravity Model in International Trade: Advances and Applications, Cambridge University Press.

Bergstrand, J.H. (1989), “The Generalized Gravity Equation, Monopolistic Competition, and the Factor-Proportions Theory in International Trade", The Review of Economics and Statistics, 71(1), 1435-153.

Bertoli, S. \& J.F.H. Moraga (2017), "Gravity Models in the Migration and Development Nexus", Revue d'économie du développement, 25(3), 69-91.

Bevan, A. \& S. Estrin \& K. Meyer (2004), "Foreign Investment Location and Institutional Development in Transition Economies", International Business Review, 13(1), 43-64.

Bhattacharya, U. \& P. Groznik (2008), "Melting Pot or Salad Bowl: Some Evidence from U.S. Investments Abroad", Journal of Financial Markets, 11(3), 228-258.

Bosker, E.M. \& H. Garretsen (2010), "Trade Costs, Market Access and Economic Geography: Why the Empirical Specification of Trade Costs Matters", in: P.A. Van Bergeijk \& S. Brakman (eds.), The Gravity Model in International Trade: Advances and Applications, Cambridge University Press.

Brakman, S. et al. (2010), "Economic and Financial Integration and the Rise of Cross-Border M\&As", in: P.A. Van Bergeijk \& S. Brakman (eds.), The Gravity Model in International Trade: Advances and Applications, Cambridge University Press. 
Aksöz-Y1lmaz, H. (2021), "Another Perspective of The Effects of Migration as A Determinant of Foreign Direct Investment: Evidence-Based on Panel Gravity Model from Turkey and OECD Countries”, Sosyoekonomi, 29(50), 169-196.

Buch, C.M. et al. (2006), "Where Enterprises Lead, People Follow? Links Between Migration and FDI in Germany", European Economic Review, 50(8), 2017-2036.

Burger, M. \& F.G. van Oort \& G.M. Linders (2009), "On the Specification of the Gravity Model of Trade: Zeros, Excess Zeros and Zero-Inflated Estimation”, Spatial Economic Analysis, 4(2), 167-90.

CEPII (2011), Notes on CEPII's distances measures: The GeoDist database, <http://www.cepii.fr/PDF_PUB/wp/2011/wp2011-25.pdf>, 31.08.2021.

Cheng, K.L. \& Y.K. Kwan (2000), "What are The Determinants of The Location of Foreign Direct Investment? The Chinese Experience", Journal of International Economics, 51(2), 379400.

Clemens, M.A. \& J.G. Williamson (2000), "Where Did British Foreign Capital Go? Fundamentals, Failures and the Lucas Paradox: 1870-1913", NBER Working Paper, No. w8028: NBER.

Combes, P. \& M. Lafourcade \& T. Mayer (2002), "Can Business and Social Networks Explain the Border Effect Puzzle?", CEPII Working Paper, No. 2: CEPII.

Correia, S. \& P. Guimaraes \& T. Zylkin (2019), "PPMLHDFE: Fast Poisson Estimation with HighDimensional Fixed Effects", <https://arxiv.org/pdf/1903.01690.pdf>, 31.08.2021.

Cuervo-Cazurra, A. (2008), "The Effectiveness of Law Against Bribery Abroad”, Journal of International Business Studies, 39(4), 634-651.

Deardorff, A.V. (1998), J. Frankel (ed.), Determinants of Bilateral Trade: Does Gravity Work in a Neoclassical World, The Regionalization of the World Economy University of Chicago Press.

Dunlevy, J.A. \& W.K. Hutchinson (1999), “The Impact of Immigration on American Import Trade in the Late Nineteenth and Early Twentieth Centuries", Journal of Economic History, 59(4), 1043-1062.

Dunlevy, J.A. \& W.K. Hutchinson (2001), "The Pro-Trade Effect of Immigration on American Exports During the Late Nineteenth and Early Twentieth Centuries", IZA Discussion Paper: 375.

Eichengreen, B. \& D.A. Irwin (1998), “The Role of History in Bilateral Trade Flows", in: The Regionalization of the World Economy, University of Chicago Press: NBER, 33-62.

Faruqee, H. (2004), "Measuring the Trade Effects of EMU”, Working Paper No. 04/154, International Monetary Fund, Washington DC.

Fidrmuc, J. (2009), “Gravity Models in Integrated Panels”, Empir Econ, 37, 435-446.

Foad, H. (2012), "FDI and Immigration: A Regional Analysis", Ann Reg Sci, 49, 237-259.

Frankel, J. \& S. Wei (1993), "Trade Blocs and Currency Blocs”, NBER Working Paper, No. 4335.

Gao, T. (2003), "Ethnic Chinese Networks and International Investment: Evidence from Inward FDI in China", Journal of Asian Economics, 14(4), 611-629.

Garas, A. \& et al. (2016), "The Relation between Migration and FDI in the OECD from a Complex Network Perspective", Advances in Complex Systems, 19 No. $06 n 071650009$.

Girma, S. \& Z. Yu (2002), "The Link Between Immigration and Trade: Evidence from the United Kingdom”, Review of World Economics, 138(1), 115-130. 
Aksöz-Y1lmaz, H. (2021), "Another Perspective of The Effects of Migration as A Determinant of Foreign Direct Investment: Evidence-Based on Panel Gravity Model from Turkey and OECD Countries”, Sosyoekonomi, 29(50), 169-196.

Globerman, S. \& D.M. Shapiro (1999), “The Impact of Government Policies on Foreign Direct Investment: The Canadian Experience”, Journal of International Business Studies, 30(3), 513-532.

Goldberger, A. (1968), "The Interpretation and Estimation of Cobb-Douglas Functions", Econometrica, 36(3), 464-472.

Gómez-Herrera, E. (2013), "Comparing Alternative Methods to Estimate Gravity Models of Bilateral Trade”, Empirical Economics, 44(3), 1087-1111.

Gould, D.M. (1994), "Immigrant Links to the Home Country: Empirical Implications for U.S. Bilateral Trade Flows", The Review of Economics and Statistics, 76(2), 302-316.

Guimarães, P. (2020), PPMLHDFE: Fast Poisson Estimation with High Dimensional Fixed Effects, <https://www.stata.com/meeting/portugal20/slides/Portugal20_Guimaraes.pdf>, 31.08.2021.

Head, K. \& J. Ries (1998), "Immigration and Trade Creation: Econometric Evidence from Canada", Canadian Journal of Economics, 31, 47-62.

Helpman, E. \& M. Melitz \& Y. Rubenstein (2008), "Estimating Trade Flows: Trading Partners and Trading Volumes", Quarterly Journal of Economics, 123, 441-87.

Helpman, E. (1984), “A Simple Theory of International Trade with Multinational Corporations”, Journal of Political Economy, 92(3), 451-71.

INSCR (2018), Polity5: Regime Authority Characteristics and Transitions Datasets, <http://www.systemicpeace.org/inscrdata.html>, 31.08.2021.

IOM (2021a), Immigration \& emigration statistics, <https://www.migrationdataportal.org/>, 15.07.2021.

IOM (2021b), Iom in Turkey, <https://www.iom.int/countries/turkey>, 15.07.2021.

Jagdambea, S. \& E. Kannan (2020), "Effects of ASEAN-India Free Trade Agreement on Agricultural Trade: The Gravity Model Approach", World Development Perspectives, 19.

Javorcik, B. \& C. Ozden \& M. Spatareanu \& C. Neagu (2011), "Migrant Networks and Foreign Direct Investment", Journal of Development Economics, 94(2), 231-241.

Kugler, M. \& H. Rapoport, (2007), "International Labor and Capital Flows: Complements or Substitutes?”, Economics Letters, 94(2), 155-162.

Leibrecht, M. \& A. Riedl (2014), "Modeling FDI Based on A Spatially Augmented Gravity Model: Evidence for Central and Eastern European Countries", The Journal of International Trade \& Economic Development, 23(8), 1206-1237.

Ligthart, J.E. \& D. Singer (2009), Do Immigrants Promote Outward Foreign Direct Investment? Evidence from the Netherlands, Unpublished: Tilburg University.

Malan, F.A. (2015), "Complementarity between FDI and Migration: Using the Fall of the Berlin Wall as a Natural Experiment", IFAC-PapersOnLine, 48(24), 201-206.

Manning, W.G. \& J. Mullahy (2001), "Estimating Log Models: To Transform or Not to Transform?", Journal of Health Economics, (20), 461-494.

Markusen, J.L. (1995), "The Boundaries of Multinational Enterprises and the Theory of International Trade", Journal of Economic Perspectives, 9(2), 169-189. 
Murat, M. \& B. Pistoresi \& A. Rinaldi (2011), “Transnational Social Capital and FDI: Evidence from Italian Associations Worldwide", Journal of Economic Development, 36(4), 1-15.

OECD (2021), <https://stats.oecd.org/>, 01.0812021.

Ozaydın, A. \& A. Ilgazi (2019), "Syrian Refugees in Terms of Direct Foreign Capital Investment", Gaziantep University Journal of Gaziantep University Faculty of Economics and Administrative Sciences, 1(1), 130-160.

Rauch, J. E. \& V. Tridade (2002), "Ethnic Chinese Networks in International Trade”, The Review of Economics and Statistics, 84(1), 116-130.

Ravenstein, E.G. (1885) “The Laws of Migration”, Journal of the Statistical Society of London, 48(2), 167-235.

Republic of Turkey Ministry of Development (2014), The Tenth Development Plan (2014-2018), <https://sbb.gov.tr/wp-content/uploads/2018/11/The_Tenth_Development_Plan_20142018.pdf>, 18.08.2021.

Silva, J.S. \& S. Tenreyro (2006), “The Log of Gravity”, The Review of Economics and Statistics, $88(4), 641-658$.

Silva, J.S. \& S. Tenreyro (2011), "Further Simulation Evidence on the Performance of the PoissonPML Estimator", Economics Letters, 112 (2), 220-222.

Tinbergen, J. (1962), Shaping the World Economy, New York: The Twentieth Century Fund.

Tong, S.Y. (2005), "Ethnic Networks in FDI and the Impact of Institutional Development", Review of Development Economics, 9(4), 563-580.

UNCTAD (2021), Foreign Direct Investment: Inward and Outward Flows and Stock- Annual, $<$ https://unctadstat.unctad.org/wds/TableViewer/tableView.aspx>, 31.08.2021.

Wahid, A.N.M. \& R. Sawkut \& R. Seetanah (2009), "Determinants of Foreign Direct Investments (FDI): Lessons from the African Economies", Journal of Applied Business and Economics, <http://www.na-businesspress.com/JABE/WahidWeb.pdf>, 31.08.2021.

Westerlund, J. \& F. Wilhelmsson (2011), "Estimating the Gravity Model Without Gravity Using Panel Data", Applied Economics, 43(6), 641-649.

World Bank (2020), Ease of Doing Business Rankings, <https://www.doingbusiness.org/en/reports/global-reports/doing-business-2020>, 31.08.2021.

Zwinkels, R.C.J. \& S. Beugelsdijk (2010), "Gravity Equations: Workhorse or Trojan Horse in Explaining Trade and FDI Patterns Across Time and Space?", International Business Review, 19, 102-115. 
Aksöz-Y1lmaz, H. (2021), “Another Perspective of The Effects of Migration as A Determinant of Foreign Direct Investment: Evidence-Based on Panel Gravity Model from Turkey and OECD Countries”, Sosyoekonomi, 29(50), 169-196.

\section{Appendix}

Table: 1

Summary Statistics

\begin{tabular}{|c|c|c|c|c|c|c|c|c|}
\hline Variable & Obs & Mean & Std. Dev. & Min & Max & Skewness & Kurtosis & Joint \\
\hline Inpolity & 340 & 2.227 & 0.065 & 2.079 & 2.302 & 0.000 & 0.000 & 0.000 \\
\hline Inpolityt & 340 & 2.078 & 0.125 & 1.945 & 2.197 & 0.366 & 0.000 & 0.000 \\
\hline Ingdp & 340 & 10.612 & 0.315 & 9.778 & 11.578 & 0.006 & 0.003 & 0.001 \\
\hline Ingdpt & 340 & 9.899 & 0.244 & 9.507 & 10.254 & 0.143 & 0.000 & 0.000 \\
\hline Indistance & 340 & 7.918 & 0.794 & 6.972 & 9.754 & 0.000 & 0.485 & 0.000 \\
\hline Inmig $_{\text {inflow }}$ & 340 & 6.256 & 1.946 & 0 & 10.815 & 0.000 & 0.019 & 0.000 \\
\hline Inmig $_{\text {outflow }}$ & 338 & 5.341 & 2.202 & 0 & 10.545 & 0.175 & 0.174 & 0.157 \\
\hline FDI $_{\text {inward }}$ & 340 & 4067.166 & 7369.212 & 0 & 44757.91 & 0.000 & 0.000 & 0.000 \\
\hline FDI $_{\text {outward }}$ & 340 & 595.393 & 2228.777 & 0 & 18232.98 & 0.000 & 0.000 & 0.000 \\
\hline
\end{tabular}

Note: Std. Dev represents standard deviation; Max and Min represent maximum and minimum values, respectively. Skewness and Kurtosis are p-values of the normality test that examines the distribution of data.

Table: 2

\section{Spearman's Rank Correlation Coefficients and Variance Inflation Factor (VIF)}

\begin{tabular}{|c|c|c|c|c|c|c|c|c|}
\hline \multicolumn{9}{|c|}{ Spearman's Rank Correlation Coefficients } \\
\hline & FDI $_{\text {inward }}$ & Inpolity & Inpolityt & lngdp & lngdpt & Indistance & lnmig $_{\text {inflow }}$ & Inmig outflow $_{\text {ow }}$ \\
\hline FDI $_{\text {inward }}$ & 1.0000 & & & & & & & \\
\hline Inpolity & 0.0425 & 1.0000 & & & & & & \\
\hline Inpolityt & 0.1687 & -0.0379 & 1.0000 & & & & & \\
\hline lngdp & 0.4140 & 0.2577 & 0.2529 & 1.0000 & & & & \\
\hline lngdpt & 0.1852 & -0.0455 & 0.8660 & 0.3215 & 1.0000 & & & \\
\hline Indistance & -0.0839 & -0.0634 & 0.0000 & 0.1016 & 0.0000 & 1.0000 & & \\
\hline Inmig inflow $_{\text {. }}$ & 0.5972 & 0.0036 & 0.0484 & 0.2138 & 0.0738 & -0.1432 & 1.0000 & \\
\hline Inmig ${ }_{\text {outflow }}$ & 0.5373 & -0.0845 & 0.1216 & 0.2565 & 0.1262 & 0.0666 & 0.8615 & 1.00 \\
\hline \multicolumn{9}{|c|}{ VIF } \\
\hline & Inpolity & Inpolityt & Ingdp & Ingdpt & Indistance & Inmig $_{\text {inflow }}$ & Inmig ${ }_{\text {outflow }}$ & Mean VIF \\
\hline & 1.09 & 3.78 & 1.19 & 3.96 & 1.06 & 1.06 & & 2.02 \\
\hline & 1.09 & 3.81 & 1.20 & 3.99 & 1.02 & & 1.04 & 2.02 \\
\hline
\end{tabular}

Note: A high correlation coefficient was estimated between the Lmig $_{\text {inflow }}$ and Lmig outlow $_{\text {variables. However, the }}$ Lmig $_{\text {inflow }}$ and Lmig $_{\text {outflow }}$ are independent variables of different models. These variables were not included together in a single model. A Variance Inflation Factor (VIF) measures multicollinearity among the independent variables in a multiple regression model. Since VIF test results are less than 5, it is at a reasonable level.

Table: 3

\section{Spearman's Rank Correlation Coefficients and VIF}

\begin{tabular}{|c|c|c|c|c|c|c|c|}
\hline & Inpolity & Inpolityt & lngdp & lngdpt & Indistance & lnmig $_{\text {inflow }}$ & Inmig ${ }_{\text {outflow }}$ \\
\hline Inpolity & 1.0000 & & & & & & \\
\hline Inpolityt & -0.0601 & 1.0000 & & & & & \\
\hline Ingdp & 0.2762 & 0.1697 & 1.0000 & & & & \\
\hline lngdpt & -0.0652 & 0.8604 & 0.2381 & 1.0000 & & & \\
\hline Indistance & -0.1318 & -0.0328 & 0.0158 & -0.0308 & 1.0000 & & \\
\hline Inmig $_{\text {inflow }}$ & 0.0239 & -0.0188 & 0.0948 & 0.0005 & -0.2103 & 1.0000 & \\
\hline \multirow[t]{4}{*}{ Inmig ${ }_{\text {outflow }}$} & -0.0893 & 0.0799 & 0.1682 & 0.0733 & 0.0455 & 0.8396 & 1.0000 \\
\hline & Inpolityt & Ingdp & Ingdpt & Indistance & Inmig $_{\text {inflow }}$ & lnmig $_{\text {outflow }}$ & Mean VIF \\
\hline & 3.62 & 1.12 & 3.74 & 1.09 & 1.06 & & 1.96 \\
\hline & 3.65 & 1.13 & 3.76 & 1.04 & & 1.01 & 1.95 \\
\hline
\end{tabular}

Note: A high correlation coefficient was estimated between the Lmig $_{\text {inflow }}$ and Lmig outlow $_{\text {variables. However, the }}$

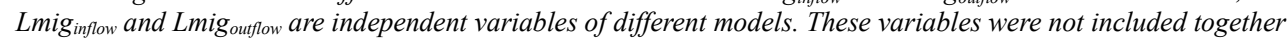
in a single model. A VIF provides a measure of multicollinearity among the independent variables in a multiple regression model. Since VIF test results are less than 5, it is at a reasonable level. 
Aksöz-Y1lmaz, H. (2021), "Another Perspective of The Effects of Migration as A Determinant of Foreign Direct Investment: Evidence-Based on Panel Gravity Model from Turkey and OECD Countries", Sosyoekonomi, 29(50), 169-196.

Table: 4

\section{Spearman's Rank Correlation Coefficients and VIF}

\begin{tabular}{|c|c|c|c|c|c|c|c|c|}
\hline \multicolumn{9}{|c|}{ Spearman's Rank Correlation Coefficients } \\
\hline & FDI $_{\text {outward }}$ & Lpolity & Lpolityt & Lgdp & Lgdpt & Ldistance & Lnmig $_{\text {inflow }}$ & Lmigoutflow \\
\hline FDI $_{\text {outward }}$ & 1.0000 & & & & & & & \\
\hline \multirow{2}{*}{$\begin{array}{l}\text { Lnpolity } \\
\text { Lnpolityt } \\
\text { Lngdp }\end{array}$} & 0.0577 & 1.0000 & & & & & & \\
\hline & $\begin{array}{l}0.1351 \\
0.2715\end{array}$ & $\begin{array}{c}-0.0379 \\
0.2577\end{array}$ & $\begin{array}{l}1.0000 \\
0.2529\end{array}$ & 1.0000 & & & & \\
\hline Lngdpt & 0.1397 & -0.0455 & 0.8660 & 0.3215 & 1.0000 & & \multirow{3}{*}{1.0000} & \\
\hline Lndistance & -0.3680 & -0.0634 & 0.0000 & 0.1016 & 0.0000 & $\begin{array}{l}1.0000 \\
-01432\end{array}$ & & \\
\hline Lnmig inflow $_{\text {. }}$ & 0.5262 & 0.0036 & 0.0484 & 0.2138 & 0.0738 & & & \\
\hline Lnmigoutflow & 0.4587 & -0.0845 & 0.1216 & 0.2565 & 0.1262 & 0.0666 & 0.8615 & 1.0000 \\
\hline \multicolumn{9}{|c|}{ VIF } \\
\hline & Lpolity & Lpolityt & Lgdp & Lgdpt & Ldistance & Lnmig $_{\text {inflow }}$ & Lmig $_{\text {outflow }}$ & Mean VIF \\
\hline & 1.09 & 3.78 & 1.19 & 3.96 & 1.06 & 1.06 & & 2.02 \\
\hline & 1.09 & 3.81 & 1.20 & 3.99 & 1.02 & & 1.04 & 2.02 \\
\hline
\end{tabular}

Note: A high correlation coefficient was estimated between the Lmig $_{\text {inflow }}$ and Lmig $_{\text {outflow }}$ variables. However, the

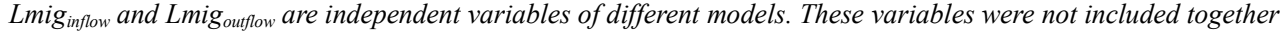
in a single model. A VIF provides a measure of multicollinearity among the independent variables in a multiple regression model. Since VIF test results are less than 5, it is at a reasonable level.

\section{Table 5: Spearman's Rank Correlation Coefficients and VIF}

\begin{tabular}{|c|c|c|c|c|c|c|c|}
\hline & Inpolity & Inpolityt & lngdp & Ingdpt & Indistance & lnmiginflow $_{\text {in }}$ & Inmig outflow $_{\text {ow }}$ \\
\hline Inpolity & 1.0000 & & & & & & \\
\hline Inpolityt & -0.0293 & 1.0000 & & & & & \\
\hline Ingdp & 0.1623 & 0.2664 & 1.0000 & & & & \\
\hline lngdpt & -0.0366 & 0.8578 & 0.3455 & 1.0000 & & & \\
\hline Indistance & -0.2519 & 0.2043 & 0.1497 & 0.2144 & 1.0000 & & \\
\hline Inmig $_{\text {inflow }}$ & 0.0310 & 0.0152 & 0.2573 & 0.0423 & 0.0071 & 1.0000 & \\
\hline \multirow{4}{*}{ Inmig $_{\text {outflow }}$} & -0.0720 & 0.1160 & 0.3041 & 0.1252 & 0.1457 & 0.8991 & 1.0000 \\
\hline & Inpolityt & Ingdp & lngdpt & Indistance & Inmiginflow & Inmig $_{\text {outflow }}$ & Mean VIF \\
\hline & 3.85 & 1.17 & 4.02 & 1.20 & 1.05 & & 2.07 \\
\hline & 3.85 & 1.17 & 4.02 & 1.17 & & 1.05 & 2.06 \\
\hline
\end{tabular}

Note: A high correlation coefficient was estimated between the Lmig inflow $_{\text {and }}$ Lmig $_{\text {outflow }}$ variables. However, the

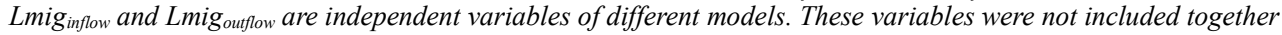
in a single model. A VIF provides a measure of multicollinearity among the independent variables in a multiple regression model. Since VIF test results are less than 5 , it is at a reasonable level.

Table: 6

Turkey's Inward FDI Positions by Total and Country Groups

\begin{tabular}{|c|c|c|c|c|c|c|c|}
\hline Years & Total Inward FDI Positions & OECD & Europe & Africa & America & Asia & Australia \\
\hline 2005 & 71297 & 61478 & 57706 & 70 & 7315 & 6206 & 0 \\
\hline 2006 & 95089 & 76823 & 76772 & 78 & 9697 & 8470 & 72 \\
\hline 2007 & 153950 & 134002 & 122827 & 151 & 18071 & 12743 & 156 \\
\hline 2008 & 80227 & 68906 & 65135 & 113 & 6865 & 8082 & 32 \\
\hline 2009 & 143723 & 125029 & 116142 & 199 & 13375 & 13982 & 24 \\
\hline 2010 & 186936 & 164489 & 146330 & 359 & 20494 & 19528 & 222 \\
\hline 2011 & 136450 & 117002 & 109379 & 176 & 10849 & 15893 & 153 \\
\hline 2012 & 189900 & 159196 & 154966 & 279 & 12559 & 21791 & 304 \\
\hline 2013 & 149764.2 & 124770.7 & 121660.7 & 162.29 & 8468.15 & 19284.59 & 188.44 \\
\hline 2014 & 182064.6 & 148699.6 & 144940.7 & 251.06 & 11678.78 & 25126.46 & 67.65 \\
\hline 2015 & 158077.6 & 128754.9 & 127019 & 194.89 & 6906.92 & 23909.08 & 47.69 \\
\hline 2016 & 148428.2 & 113579.5 & 115363.8 & 122.76 & 6287.2 & 26586.22 & 68.26 \\
\hline 2017 & 196877.4 & 150664.5 & 150414.2 & 199.62 & 9703.21 & 36397.04 & 163.34 \\
\hline 2018 & 145554.6 & 105555.1 & 113387.5 & 130.85 & 6320.61 & 25588.56 & 127.07 \\
\hline 2019 & 161650.1 & 110679.3 & 108625.7 & 204.23 & 5207.56 & 47476.91 & 135.75 \\
\hline
\end{tabular}

Source: OECD Database.

Note: All FDI activities and U.S. dollars, million. The bolded values indicate the country group with the highest inward FDI positions. 
Table: 7

Turkey's Outward FDI Positions by Total and Country Groups

\begin{tabular}{|c|c|c|c|c|c|c|c|}
\hline Years & Total Outward FDI Positions & OECD & Europe & Africa & America & Asia & Australia \\
\hline 2005 & 8315 & 4684 & 5083 & 86 & 293 & 2853 & 0 \\
\hline 2006 & 8866 & 4922 & $\mathbf{5 3 9 5}$ & 90 & 293 & 3076 & 1 \\
\hline 2007 & 12210 & 6138 & 7968 & 173 & 299 & 3706 & 0 \\
\hline 2008 & 17846 & 9044 & 10861 & 381 & 1476 & 4777 & 1 \\
\hline 2009 & 22250 & 10935 & 13223 & 470 & 2058 & 5968 & 6 \\
\hline 2010 & 22509 & 10660 & 12613 & 831 & 2452 & 5967 & 68 \\
\hline 2011 & 27681 & 13897 & 15089 & 845 & 3863 & 7356 & 61 \\
\hline 2012 & 30968 & 16725 & 18428 & 799 & 2449 & 8499 & 274 \\
\hline 2013 & 33317.89 & 19211.7 & 21065.96 & 1034.73 & 2917.02 & 8033.01 & 267.16 \\
\hline 2014 & 39513.27 & 22480.56 & 24346.69 & 1126.04 & 3236.07 & 10482.85 & 321.6 \\
\hline 2015 & 35614.96 & 19879.9 & 25793.94 & 966.63 & 3052.44 & 5530.37 & 271.58 \\
\hline 2016 & 38368.58 & 22665.26 & 29278.93 & 1258.8 & 2868.27 & 4767.04 & 195.54 \\
\hline 2017 & 45583.37 & 26993.54 & 35741.85 & 1568.69 & 3322.31 & 4819.25 & 131.27 \\
\hline 2018 & 44496.57 & 29563.32 & 36685.26 & 1265.76 & 2240.15 & 4367.31 & -61.91 \\
\hline 2019 & 48979.37 & 32232.17 & 37476.9 & 1899.56 & 4197.91 & 5427.36 & -22.36 \\
\hline
\end{tabular}

Source: OECD Database.

Note: All FDI activities and U.S. dollars, million. The bolded values indicate the country group with the highest outward FDI positions.

\section{Table: 8}

\section{Cross Section Dependence and Unit Root Test}

\begin{tabular}{|c|c|c|c|c|c|c|c|c|c|}
\hline Variable & FDI $_{\text {inward }}$ & FDI $_{\text {outward }}$ & Inpolity & Inpolityt & lnmig $_{\text {inflow }}$ & lnmig $_{\text {outflow }}$ & Indistance & lngdp & Ingdpt \\
\hline & 23.47 **** & $6.44 * * *$ & & $56.83^{* * * *}$ & $4.13^{* * *}$ & $7.80 * * *$ & & $51.60 * * *$ & $56.83 * * *$ \\
\hline IPS & $-3.14 * * *$ & 9.298 & $-1.923 * * *$ & & $-5.930 * * *$ & $-3.382 * * *$ & & 0.377 & \\
\hline Fisher PP & $3.363 * * *$ & -3.422 & -4.472 & 6.077 & $0.684 * * *$ & $4.268^{* * * *}$ & -4.472 & -4.420 & -4.472 \\
\hline Fisher ADF & $2.777 * * *$ & -3.753 & $3.447 * * *$ & -4.472 & $10.924^{* * * *}$ & $5.404 * * *$ & -4.472 & -0.397 & -4.472 \\
\hline CIPS & $-2.150^{* * *}$ & -1.417 & 2.044 & 2.610 & $-2.201 * *$ & -0.661 & 2.610 & -1.432 & 2.610 \\
\hline
\end{tabular}

Note: $* * * p<0.01, * * p<0.05, * p<0.1$. Pesaran (2004) suggested test statistics in equation (5) as an alternative to the Breusch-Pagan LM test for testing cross-sectional dependence when $T$ is small, and $N$ is large. Monte-Carlo simulations showed that the test performance of Pesaran is better than the Breusch-Pagan LM test performance for $N>T . C D=\sqrt{\frac{2 T}{N /(N-1)}}\left(\sum_{i=1}^{N-1} \sum_{J=i+1}^{N} \hat{\rho}_{i j}\right)$ and $\hat{\rho}_{i j}=\hat{\rho}_{j i}=\frac{\sum_{t=1}^{T} e_{i t} e_{j t}}{\left(\sum_{t=1}^{T} e_{i t}^{2}\right)^{1 / 2}\left(\sum_{t=1}^{T} e_{j t}^{2}\right)^{1 / 2}} \cdot e_{i t}$, shows the estimated residuals from each unit. In panel data analysis, it is necessary to test the cross-section dependence in the series before deciding on the model specification. The unit root tests to be used vary depending on whether there is a crosssectional dependence or not. The $H_{0}$ hypothesis, which states that there is no cross-sectional dependence, was rejected. In the presence of cross-section dependence, should be considered second-generation stationarity that considers the cross-section dependence. The stationarity of the series, whether they contain a unit root or not, was tested with the second-generation unit root tests such as IPS, Fisher PP, Fisher ADF, and CIPS tests. In the test results of all the stationarity tests of the lndistance, Ingdp and lngdpt series, the primary hypothesis that the series contains a unit root could not be rejected against the alternative hypothesis that the series does not contain a unit root. 